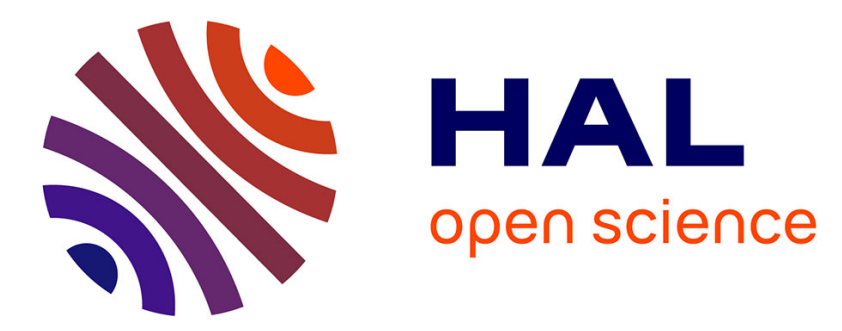

\title{
Generation of CO2-rich melts during basalt magma ascent and degassing
}

\author{
Michel Pichavant, Ida Di Carlo, Silvio G. Rotolo, Bruno Scaillet, Alain
}

Burgisser, Nolwenn Le Gall, Caroline Martel

\section{To cite this version:}

Michel Pichavant, Ida Di Carlo, Silvio G. Rotolo, Bruno Scaillet, Alain Burgisser, et al.. Generation of CO2-rich melts during basalt magma ascent and degassing. Contributions to Mineralogy and Petrology, 2013, 166, pp.545-561. 10.1007/s00410-013-0890-5 . insu-00828151

\section{HAL Id: insu-00828151 https://hal-insu.archives-ouvertes.fr/insu-00828151}

Submitted on 30 May 2013

HAL is a multi-disciplinary open access archive for the deposit and dissemination of scientific research documents, whether they are published or not. The documents may come from teaching and research institutions in France or abroad, or from public or private research centers.
L'archive ouverte pluridisciplinaire HAL, est destinée au dépôt et à la diffusion de documents scientifiques de niveau recherche, publiés ou non, émanant des établissements d'enseignement et de recherche français ou étrangers, des laboratoires publics ou privés. 


\title{
Generation of $\mathrm{CO}_{2}$-rich melts during basalt magma ascent
}

\section{and degassing}

\author{
Michel Pichavant ' Ida Di Carlo 'Silvio G. Rotolo ` Bruno Scaillet ' Alain Burgisser ' \\ Nolwenn Le Gall · Caroline Martel
}

Received : 2012 / Accepted : 201x/ Published online:

Communicated by M. Schmidt.

M. Pichavant (corresponding author), I. Di Carlo, B. Scaillet, A. Burgisser, N. Le Gall, C. Martel

Université d'Orléans, ISTO, UMR 7327, 45071, Orléans, France, and CNRS/INSU, ISTO, UMR 7327, 45071 Orléans, France, and BRGM, ISTO, UMR 7327, BP 36009, 45060

Orléans, France

e-mail : pichavan@cnrs-orleans.fr

I. Di Carlo, S. Rotolo

Dipartimento di Scienze della Terra e del Mare, Università di Palermo, Via Archirafi 22, 90123 Palermo, Italy, and Istituto Nazionale di Geofisica e Vulcanologia (INGV), Sezione di Palermo, Via U. La Malfa 153, 90146 Palermo, Italy 
Abstract To test mechanisms of basaltic magma degassing, continuous decompressions of volatile-bearing (2.7-3.8 wt $\% \mathrm{H}_{2} \mathrm{O}, 600-1300 \mathrm{ppm} \mathrm{CO}_{2}$ ) Stromboli melts were performed from $250-200$ to $50-25 \mathrm{MPa}$ at $1180-1140^{\circ} \mathrm{C}$. Ascent rates were varied from 0.25 to $\sim 1.5$ $\mathrm{m} / \mathrm{s}$. Glasses after decompression show a wide range of textures, from totally bubble-free to bubble-rich, the latter with bubble number densities from $10^{4}$ to $10^{6} / \mathrm{cm}^{3}$, similar to Stromboli pumices. Vesicularities range from 0 to $\sim 20 \mathrm{vol} \%$. Final melt $\mathrm{H}_{2} \mathrm{O}$ concentrations are homogeneous and always close to solubilities. In contrast, the rate of vesiculation controls the final melt $\mathrm{CO}_{2}$ concentration. High vesicularity charges have glass $\mathrm{CO}_{2}$ concentrations that follow theoretical equilibrium degassing paths whereas glasses from low vesicularity charges show marked deviations from equilibrium, with $\mathrm{CO}_{2}$ concentrations up to one order of magnitude higher than solubilities. FTIR profiles and maps reveal glass $\mathrm{CO}_{2}$ concentration gradients near the gas-melt interface. Our results stress the importance of bubble nucleation and growth, and of volatile diffusivities, for basaltic melt degassing. Two characteristic distances, the gas interface distance (distance either between bubbles or to gas-melt interfaces) and the volatile diffusion distance control the degassing process. Melts containing numerous and large bubbles have gas interface distances shorter than volatile diffusion distances, and degassing proceeds by equilibrium partitioning of $\mathrm{CO}_{2}$ and $\mathrm{H}_{2} \mathrm{O}$ between melt and gas bubbles. For melts where either bubble nucleation is inhibited or bubble growth is limited, gas interface distances are longer than volatile diffusion distances. Degassing proceeds by diffusive volatile transfer at the gas-melt interface and is kinetically limited by the diffusivities of volatiles in the melt. Our experiments show that $\mathrm{CO}_{2}$-oversaturated melts can be generated as a result of magma decompression. They provide a new explanation for the occurrence of $\mathrm{CO}_{2}$-rich natural basaltic glasses and open new perspectives for understanding explosive basaltic volcanism. 
Keywords Basaltic melts, Volatiles, Decompression experiments, Magma degassing, $\mathrm{CO}_{2^{-}}$ oversaturation, Explosive volcanism

\section{Introduction}

During magma ascent, decompression leads to the exsolution of volatiles (mainly $\mathrm{H}_{2} \mathrm{O}$ and $\mathrm{CO}_{2}$ ) from the melt, and to their progressive transfer from the deep Earth to the atmosphere. Gas emissions are manifestations of magma ascent towards the Earth's surface. Measurement of gas compositions and fluxes is one of the main tools for monitoring active volcanoes (e.g., Aiuppa et al. 2010a). Because of the relatively high temperatures, low volatile concentrations and viscosities of basaltic magmas, their degassing is commonly viewed as a nearequilibrium process (Sparks et al. 1994). The behaviour of volatiles during basaltic magma degassing is classically assumed to follow solubility laws (e.g. Dixon et al. 1995; Lesne et al. 2011a; b), with $\mathrm{CO}_{2}$ being exsolved deeper (and therefore earlier upon ascent) than $\mathrm{H}_{2} \mathrm{O}$ (Bottinga and Javoy 1990a; Dixon and Stolper 1995; Burton et al. 2007; Shinohara et al. 2008; Allard 2010). Several gas-melt saturation codes (e.g. Papale et al. 2006) now enable theoretical equilibrium decompression paths and depths of degassing to be calculated. Recently, isobaric experiments have confirmed equilibrium degassing models for basaltic melts (Lesne et al. 2011c).

There are however several observations that do not fit into a simple, unique, equilibrium degassing model for basaltic magmas. (1) Explosive basaltic eruptions, known both at the Earth's surface and in deep oceans (e.g. Head and Wilson 2003), imply sudden (as opposed to gradual) release of magmatic volatiles. Gas buildup in the conduit, either driven by the evacuation of a gas foam (e.g. Jaupart and Vergniolle 1988) or by the coalescence of gas bubbles, has been the preferred model for explosive basaltic volcanism although 
fragmentation of volatile-oversaturated melts warrants more detailed consideration. (2) $\mathrm{CO}_{2}$ concentrations markedly higher than solubilities have been found in numerous basaltic glasses, especially MORB glasses for which eruption pressures are well known (e.g. Dixon et al. 1988; Pineau and Javoy 1994; Saal et al. 2002; Aubaud et al. 2004 and references therein). In some of these glasses, kinetic fractionation of carbon and noble gases isotopes has been observed during magma ascent from the chamber to the seafloor (Aubaud et al. 2004). (3) Theoretical considerations have stressed that nucleation of $\mathrm{CO}_{2}$ bubbles in MORB melts requires degrees of supersaturation from 1.5 at $>600 \mathrm{MPa}$ to up to 7 at $<100 \mathrm{MPa}$ (Bottinga and Javoy 1990b). Therefore, gas-melt separation in basaltic magmas may not be as easy as commonly postulated (Sparks et al. 1994). More generally, mechanisms of basaltic magmas degassing need a detailed re-evaluation. The implications range from the interpretation of volcanic gas data to more global issues such as the chemistry of planetary atmospheres and the determination of the carbon content of the Earth's mantle (Cartigny et al. 2008).

Recent numerical simulations have emphasized dynamic instabilities of gas bubbles during buoyancy-driven flow of basaltic magmas (Suckale et al. 2010). Experimental simulations of magma vesiculation and degassing are available for rhyolites to dacites (Mourtada-Bonnefoi and Laporte 2002; 2004; Mangan and Sisson 2000; 2005; Gardner and Ketcham 2011; Nowak et al. 2011) but are lacking for basaltic melts. In this paper, we present the first experiments to track degassing of $\mathrm{H}_{2} \mathrm{O}$ - and $\mathrm{CO}_{2}$-bearing natural basaltic magmas using high temperature decompression experiments.

\section{Scaling of the decompression experiments}

In this study, decompression experiments were scaled against a reference volatile-rich, persistently degassing, basaltic volcano, Stromboli (Aeolian Islands, Italy). Magma ascent 
and degassing at Stromboli were simulated as closely as possible by simultaneously adjusting the different experimental variables to values appropriate to the natural system. Stromboli's regular mild-explosive activity is occasionally interrupted by much more energetic events, major explosions and eruptive paroxysms (Rosi et al. 2000). These highly hazardous eruptions have been interpreted to result from the ascent and arrival in the volcanic edifice of a volatile-rich crystal-poor magma ("golden pumice") batch (Pichavant et al. 2009; 2011; Metrich et al. 2010) or, alternatively, from the bursting of $\mathrm{CO}_{2}$-rich gas slugs generated at 8-10 km depth (Allard 2010).

In this study, continuous decompression experiments of bubble-free but volatilebearing basaltic melts were performed at high temperatures. Our experimental strategy thus differs from studies where melt decompression is simulated by a series of isobaric experiments at progressively decreasing pressures (e.g. Lesne et al. 2011c). Performing decompression experiments requires several parameters to be fixed. (1) The same basaltic composition (prepared from a pumice emitted during one of Stromboli's paroxysmal events) has been used in all experiments; pre-decompression melts had a restricted range of dissolved $\mathrm{H}_{2} \mathrm{O}$ and $\mathrm{CO}_{2}$ concentrations (2.7-3.8 wt\% and 600-1300 ppm respectively), overlapping in part with volatile concentrations in Stromboli glass inclusions (Table 1; Metrich et al. 2010). (2) Decompressions started at initial pressures $\left(\mathrm{P}_{\text {init }}\right)$ of either 200 or $250 \mathrm{MPa}$. This pressure range matches the depth of the magma reservoir source of golden pumice melts at Stromboli (Pichavant et al. 2009; Metrich et al. 2010). (3) Temperature (T) was mostly kept constant $\left(1150^{\circ} \mathrm{C}\right)$ or, less frequently, slightly varied (from 1180 to $1150^{\circ} \mathrm{C}$ and 1150 to $1140^{\circ} \mathrm{C}$ ) in a range consistent with temperatures of golden pumice melts (Di Carlo et al. 2006; Pichavant et al. 2009). (4) Concerning magma ascent rates, petrological estimates (based on plagioclase reaction rims and lack of microlites in "golden pumices", I Di Carlo, personal communication 2010) have yielded durations in the range from 1 to $10 \mathrm{~h}$ for ascent of "golden pumice" from 
their $8 \mathrm{~km}$ depth source. This corresponds to ascent rates from 0.2 to $2 \mathrm{~m} / \mathrm{s}$, in excellent agreement with results for shoshonite magma ascent at Vulcanello, a nearby system closely similar (tectonic setting, magma composition, ascent mechanism) to Stromboli (Vetere et al. 2007). Consequently, a range of ascent rates $\left(\mathrm{v}_{\mathrm{ramp}}=0.25,0.5,0.65,1, \sim 1.5 \mathrm{~m} / \mathrm{s}\right) \mathrm{was}$ investigated (for correspondence between ascent and decompression rates, see Table 2). Both constant (one ramp) and variable (two ramps) rate decompressions were performed since, at Stromboli, magma ascent is expected to be modified from $~ 50 \mathrm{MPa}$ upwards, as the base of the crystal-rich body is encountered (Landi et al. 2008). (5) Decompression ramps ended at final pressures $\left(\mathrm{P}_{\text {fin }}\right)$ of either 50 or $25 \mathrm{MPa}$, and charges were immediately quenched once the final pressure was reached.

\section{Experimental and analytical methods}

Two types of experiments were performed in this study. Synthesis experiments served to produce bubble-free $\mathrm{H}_{2} \mathrm{O}$ - and $\mathrm{CO}_{2}$-bearing basaltic glasses to be used in the decompression experiments (Table 1). In most cases, the syntheses and decompressions were performed independently from each other. Volatile-bearing melts were pre-synthesized at high temperatures and pressures under isobaric conditions and the resulting glasses used as starting materials in subsequent decompression experiments. Less frequently, the melt synthesis step was followed in the same experiment by the decompression step.

Starting materials

All experiments used pumice sample PST-9 as starting material. It contains about 10\% crystals (Di Carlo et al. 2006; Pichavant et al. 2011). The sample was crushed to $\sim 50 \mu \mathrm{m}$ and 
either used directly as powder or converted to glass by fusing the powder at $1 \mathrm{~atm}, 1400^{\circ} \mathrm{C}$ for a few hours in air.

All experiments were performed with the sealed capsule method. Capsules were in all cases made of $\mathrm{Au}_{80} \mathrm{Pd}_{20}$, to minimize iron loss from the basaltic melt as a result of alloying with the metallic container (Di Carlo et al. 2006; Pichavant et al. 2009). For the synthesis experiments, $\mathrm{H}_{2} \mathrm{O}$ was added as demineralised water and $\mathrm{CO}_{2}$ as $\mathrm{Ag}_{2} \mathrm{C}_{2} \mathrm{O}_{4}$. PST-9 (either glass or pumice), $\mathrm{H}_{2} \mathrm{O}$ and $\mathrm{Ag}_{2} \mathrm{C}_{2} \mathrm{O}_{4}$ weights were adjusted so as to reproduce the preeruptive volatile concentrations of Stromboli golden pumice melts, as constrained from previous experiments (Pichavant et al. 2009). For the decompression experiments, presynthesized volatile-bearing glass, either powder or small blocks, were loaded in $\mathrm{Au}_{80} \mathrm{Pd}_{20}$ capsules which were then welded shut. No additional volatile was added to those already present as dissolved components in the glass, and this resulted in low proportions of free fluid (1-2 wt\% maximum) in decompression capsules prepared from pre-synthesized glass. A few decompression capsules were prepared with pumice powder plus $\mathrm{H}_{2} \mathrm{O}$ and $\mathrm{Ag}_{2} \mathrm{C}_{2} \mathrm{O}_{4}$, yielding slightly higher (6-7 wt\% maximum) fluid proportions because melt synthesis was in this case directly followed by decompression. At the difference of experiments starting from glass, a few crystals are present in experiments performed with pumice.

Equipment and run procedure

All experiments were performed in the same internally-heated pressure vessel working vertically and pressurized with $\mathrm{Ar}-\mathrm{H}_{2}$ gas mixtures, obtained by sequential loading of $\mathrm{H}_{2}$ and Ar at room temperature (Di Carlo et al. 2006; Pichavant et al. 2009). In all experiments, a pressure of 0.5 bar $\mathrm{H}_{2}$ was initially applied. Then Ar was pumped into the vessel up to a pressure depending on the final conditions to be attained. Although experimental $\mathrm{fO}_{2}$ were 
not measured, previous work (Di Carlo et al. 2006; Pichavant et al. 2009) using the same vessel, procedure and starting materials have provided a precise empirical calibration scale so that experimental $\mathrm{fO}_{2}$ in this study can be considered close to $\mathrm{NNO}+1$, where $\mathrm{NNO}$ is the $\mathrm{fO}_{2}$ of the Ni-NiO equilibrium at the pressure and temperature of interest. We emphasize that NNO+1 represents average redox conditions for the group of experiments reported here. Although $\mathrm{fO}_{2}$ changes occur during decompression, these are of small magnitude as shown by the constant (and always very low) amount of Fe-Ti oxides present in run products. Experimental redox conditions in this study are moderately oxidizing, implying that the C-O$\mathrm{H}$ fluid phase is essentially composed of $\mathrm{H}_{2} \mathrm{O}$ and $\mathrm{CO}_{2}$.

Total pressure was recorded by a transducer calibrated against a Heise gauge (uncertainty \pm 20 bars). Decompression was controlled manually, by bleeding the pressurizing gas mixture with a micrometering valve. A double winding molybdenum furnace was used, allowing near isothermal conditions in the $2-3 \mathrm{~cm}$ long hot spot (gradient $<2-3$ $\left.{ }^{\circ} \mathrm{C} / \mathrm{cm}\right)$. Temperature was monitored with a Eurotherm controller and measured using two type $S$ thermocouples (uncertainty $\pm 5^{\circ} \mathrm{C}$ ). For the non-isothermal experiments, temperature was manually varied by periodic adjustments of the controller's setpoint. Both pressure and temperature readouts were permanently recorded during decompression and the different decompression parameters extracted from the datafile.

All experiments were terminated by drop-quenching the sample holder at essentially constant pressure, resulting in quench rates of $\sim 100{ }^{\circ} \mathrm{C} / \mathrm{s}$ (Di Carlo et al. 2006). Capsules were weighed to check for leaks and then opened.

Analytical methods 
A few capsules were cut in the middle for textural observations of the entire charge. For the other capsules, textural observations were made on fragments of run products. Both microscopic and SEM observations were performed, the latter using the JEOL WINSET JSM 6400 instrument at ISTO, Orléans. Bubble fractions (vol\% bubbles or vesicularities) were determined on photomicrographs of run products with the ImageJ software and assuming Delesse's law (equality of area and volume fractions). To complement these 2D data, blocks $\left(1-10 \mathrm{~mm}^{3}\right)$ from 5 selected charges were analyzed by X-ray microtomography with the Nanotom 180 instrument by GE Sensing, phoenix|x-ray at ISTO, Orléans. Voxel sizes ranged between 2 and $3.5 \mu \mathrm{m}$, allowing the determination of bubble numbers, sizes and densities in addition to vesicularities.

Electron microprobe analyses of experimental glasses (and of crystals in experiment R16-1 where crystals were sufficiently large) were performed with the Cameca SX-50 instrument of the joint BRGM-CNRS facility at Orléans. The data mainly served to check the melt composition during decompression and evaluate the extent of Fe loss. Analyses were carried out under an acceleration voltage of $15 \mathrm{kV}$, a counting time of $10 \mathrm{~s}$ and a sample current of $6 \mathrm{nA}$. For glass analysis, the beam was defocused to a size of $\sim 10 \mu \mathrm{m}$. Silicate minerals were used as standards. Estimated relative analytical errors are $1 \%$ for $\mathrm{SiO}_{2}, \mathrm{Al}_{2} \mathrm{O}_{3}$, $\mathrm{CaO}, 3 \%$ for $\mathrm{FeO}, \mathrm{MgO}, \mathrm{TiO}_{2}$ and $5 \%$ for $\mathrm{MnO}, \mathrm{Na}_{2} \mathrm{O}, \mathrm{K}_{2} \mathrm{O}, \mathrm{P}_{2} \mathrm{O}_{5}$. Fe losses, calculated for the crystal-free charges by comparing the electron microprobe compositions of starting and final glasses and, for the crystal-bearing charge R16-1, from mass-balance calculations (Pichavant et al. 2009), were of negligible importance (1-2\% relative).

Concentrations of $\mathrm{H}_{2} \mathrm{O}$ and $\mathrm{CO}_{2}\left(\right.$ as $\left.\mathrm{CO}_{3}{ }^{2-}\right)$ in glasses were determined by IR spectroscopy on doubly-polished thin sections prepared from glass fragments. Both a Nicolet Magna 760 spectrometer attached to a NicPlan microscope (analytical spots) and a Nicolet 6700 spectrometer attached to a Continuum microscope (spots, 1D profiles, 2D maps) were 
used. Spectra were acquired between 650 and $7400 \mathrm{~cm}^{-1}$ on samples mostly 40-60 $\mu \mathrm{m}$ thick. Profiles and maps, plus a few spots, were obtained on thicker $(\sim 150 \mu \mathrm{m})$ samples. An IR source, a $\mathrm{KBr}$ beamsplitter and a liquid nitrogen cooled MCT/A detector were used.

Resolution was set to $2-4 \mathrm{~cm}^{-1}$ and spectra were accumulated for 128-256 scans. Between 2 to 6 spots (aperture $40-100 \mu \mathrm{m}$ ) were analyzed on each sample. Several glasses were analysed in duplicate (i.e. different glass wafers from the same experiment) and one in triplicate, results being averaged. Concentrations of $\mathrm{H}_{2} \mathrm{O}$ and $\mathrm{CO}_{2}$ were determined from the BeerLambert law. Sample thicknesses were measured microscopically to $+/-1-2 \mu \mathrm{m}$. Densities of experimental glasses were calculated from the density of the anhydrous starting glass measured at room conditions and using a partial molar volume of $\mathrm{H}_{2} \mathrm{O}$ in glass of $12 \mathrm{~cm}^{3} / \mathrm{mol}$ (see Pichavant et al. 2009). $\mathrm{H}_{2} \mathrm{O}$ concentrations were obtained from the absorbance of the $3530 \mathrm{~cm}^{-1}$ band, taking $\varepsilon_{3530}=64 \mathrm{~L} / \mathrm{mol} . \mathrm{cm}$ and a linear baseline between $\sim 3800$ and $\sim 2500$ $\mathrm{cm}^{-1}$. For $\mathrm{CO}_{2}$, the absorbance of the $1515 \mathrm{~cm}^{-1}$ band was measured on substracted spectra (Dixon et al. 1995; Pichavant et al. 2009), taking $\varepsilon_{1515}=363 \mathrm{~L} / \mathrm{mol} . \mathrm{cm}$. The spectrum used for the substraction is that of a volatile-free PST-9 glass. The detection limit for $\mathrm{CO}_{2}$ (also taken as the absolute uncertainty of the $\mathrm{CO}_{2}$ analyses) is $\sim 50 \mathrm{ppm}$. The $1 \mathrm{D}$ profiles (30 to 50 points) and 2D maps ( 300 points) were collected with a 50x50 $\mu \mathrm{m}$ aperture and a distance between points (i.e. centers) of either 20 or $25 \mu \mathrm{m}$. The data were analyzed with the Omnic software and concentration profiles and maps constructed.

All equilibrium gas-melt computations (saturation isobars, $\mathrm{H}_{2} \mathrm{O}$ and $\mathrm{CO}_{2}$ solubilities, closed-system decompression paths) were calculated with the model of Papale et al. (2006).

\section{Experimental results}


Full information about the glass synthesis experiments is given in Table 1 and about the decompression experiments in Table 2. Tables 3 and 4 summarize the FTIR and X-ray tomography data, respectively. Pressure-time trajectories for two representative decompression experiments are illustrated in Fig. 1. The heating up period (not shown) is followed by a dwell of typically 600-1200 s, occasionally longer, before decompression starts. For constant decompression experiments, the ascent rate $\left(\mathrm{v}_{\mathrm{ramp}}\right)$ is kept constant along the ramp until $\mathrm{P}_{\text {fin }}$ is attained (Fig. 1A). For variable decompression experiments, the decompression path is divided into two ramps, the first above and the second below $50 \mathrm{MPa}$, each with a specific $v_{\text {ramp }}$ (Fig. 1B).

Pre-decompression glasses

All pre-decompression glasses were bubble-free. SEM observations reveal the presence of rare quench crystals and of small $(<5 \mu \mathrm{m})$ Fe-Ti oxides. Pre-decompression glasses divide into two compositional groups. The first (S1 to S3, Table 1) corresponds to melts synthesized at $\sim 200 \mathrm{MPa}$. Glass $\mathrm{CO}_{2}$ concentrations are of the order of $600-850 \mathrm{ppm}$ and $\mathrm{H}_{2} \mathrm{O}$ concentrations between 2.7 to $3.6 \mathrm{wt} \%$. Although several S3 glasses were used directly in decompression experiments without being analyzed, they are expected to have volatile concentrations in the same range because $\mathrm{XH}_{2} \mathrm{O}$ in. and \% fluid (Table 1) were identical for all $\mathrm{S} 3$ capsules. The second group of melts, synthesized at $\sim 250 \mathrm{MPa}(\mathrm{S} 4, \mathrm{~S} 5)$, has $\mathrm{H}_{2} \mathrm{O}$ concentrations (2.7 to $3.8 \mathrm{wt} \%$ ) equivalent to the first group, but higher $\mathrm{CO}_{2}$ concentrations (900-1300 ppm, Table 1).

Post-decompression textures and vesicularities 
Post-decompression charges were generally glassy. They contain various amounts of bubbles (Fig. 2) and are very crystal-poor. Only charge R16-1 (from the longest decompression experiment, Table 2) crystallized significant amounts (12 wt $\%$ ) of clinopyroxene plus olivine. Tiny $(\leq 1-2 \mu \mathrm{m})$ oxide crystals (Ti-bearing magnetite, Di Carlo et al. 2006; Pichavant et al. 2009) occur commonly but always in very small amounts. Some charges contain quench crystals identified from SEM (Table 2). The two R11 charges (Table 2) came out as fine-grained powders. The recovery of powders (the normal case is glassy blocks) indicates glass fragmentation in this particular experiment which spent the shortest time above $50 \mathrm{MPa}$ and the longest between 50 and $25 \mathrm{MPa}$ of all variable rate decompression experiments.

Three types of bubbles were distinguished (Fig. 2). Type 1 occurs at the glass-capsule interface. They range from 150 to $>500 \mu \mathrm{m}$ and represent the space filled by the free vapour phase in the capsule. Large rounded cavities found in many glass fragments are probably broken type 1 bubbles. In comparison, type 2 and 3 bubbles both occur inside the glass (Fig. 2). Type 3 bubbles have sizes in the $10-50 \mu \mathrm{m}$ and type 2 in the 50 to $350 \mu \mathrm{m}$ range. These two bubble types are interpreted to mark homogeneous bubble nucleation within the melt, the large size of type 2 bubbles reflecting both diffusive bubble growth and coalescence.

Vesicularities range from 0 to $20 \mathrm{vol} \%$. There is a good match between data from $2 \mathrm{D}$ measurements and 3D X-ray tomography, with maximum differences of $\sim 2$ vol\% (taken as the analytical error) between the two methods (Table 2). Vesicularities of charges ran together in the same decompression experiment (for example of charges 1, 2, 3 from experiments R1, R4 and R12, Table 2) are tightly grouped, suggesting that they are determined by the experimental variables (volatile concentrations of starting melts, decompression parameters) rather than by the physical state of starting materials (either glass powder, glass blocks, or pumice powder, Table 2). Samples with low vesicularities $(<5$ vol\%) come from experiments decompressed either at constant rates to $50 \mathrm{MPa}(\mathrm{R} 1, \mathrm{R} 4$, 
$\mathrm{R} 16)$ or at variable rates to $25 \mathrm{MPa} \mathrm{P}_{\text {fin }}(\mathrm{R} 12-15$, Table 2). Charges with the highest vesicularities are those decompressed under constant ascent rates to $25 \mathrm{MPa} \mathrm{P}_{\text {fin }}(\mathrm{R} 5, \mathrm{R} 10$, Table 2; Fig. 3).

Bubble number densities range from $10^{4}$ to $10^{6} / \mathrm{cm}^{3}$ (Table 4), in the same range as in basaltic pumices from Stromboli (Polacci et al. 2006). Although the number of 3D data is limited, BND stays constant or decreases slightly when $\mathrm{P}_{\text {fin }}$ decreases and when $\mathrm{v}_{\mathrm{ramp}}$ decreases in the 50-25 MPa range. In contrast, vesicularities strongly increase when lowering $\mathrm{P}_{\text {fin. }}$. These trends are consistent with bubble nucleation systematics in rhyolitic melts (Mourtada-Bonnefoi and Laporte 2004). Bubble diameters range from 10-20 to $330 \mu \mathrm{m}$ (Table 4). Both the average diameter and the maximum diameter strongly increase with decreasing $\mathrm{P}_{\text {fin }}$ as well as with decreasing $\mathrm{v}_{\mathrm{ramp}}$ in the 50-25 MPa range. Histograms have asymmetrical shapes as indicated by the difference between maximum and average bubble diameters (Table 4), suggesting that bubble nucleation is accompanied by diffusive bubble growth and coalescence.

Post-decompression glass volatile concentrations

Volatile concentrations in glasses are shown in Figs. 4 and 5 respectively for the constant and variable decompression rate experiments. The constant rate experimental data points divide into two groups. Glasses decompressed to $\sim 50 \mathrm{MPa} \mathrm{P}_{\text {fin }}$ have $\mathrm{H}_{2} \mathrm{O}$ concentrations between 1.70 and $2.23 \mathrm{wt} \%$ and $\mathrm{CO}_{2}$ concentrations between 198 and 469 ppm (Table 3). Compared to pre-decompression glasses (Table 1), both volatiles are significantly depleted in postdecompression glasses. However, the data points plot well above the $50 \mathrm{MPa}$ gas-melt saturation isobar, except for charge 16-2 if error bars are considered. In the same way, measured $\mathrm{CO}_{2}$ concentrations largely exceed calculated values for closed-system equilibrium 
decompression paths (Fig. 4). In contrast, glasses decompressed to $25 \mathrm{MPa} \mathrm{P}_{\text {fin }}$ plot either on or close to their corresponding gas-melt saturation isobar and on extensions of closed-system equilibrium decompression paths. They have $\mathrm{H}_{2} \mathrm{O}$ concentrations between 1.32 and 1.43 wt $\%$ and $\mathrm{CO}_{2}$ concentrations ranging from below detection (i.e. $\left.\leq 50 \mathrm{ppm}, \mathrm{R} 5\right)$ to $\sim 100 \mathrm{ppm}(\mathrm{R} 10$, Table 3). Data at constant $v_{\text {ramp }}(0.64 \mathrm{~m} / \mathrm{s}: \mathrm{R} 1, \mathrm{R} 10 ; 1 \mathrm{~m} / \mathrm{s}: \mathrm{R} 4, \mathrm{R} 5)$ show that decreasing $\mathrm{P}_{\text {fin }}$ leads to a progressive decrease of glass $\mathrm{H}_{2} \mathrm{O}$ and $\mathrm{CO}_{2}$ concentrations. However, the observed volatile depletions differ from those expected along closed-system equilibrium decompression paths. $\mathrm{CO}_{2}$ appears to be degassed at low pressures in the experiments, mostly between 50 and $25 \mathrm{MPa}$, whereas one would expect it to be lost much earlier, i.e., at pressures $>50 \mathrm{MPa}$, on the basis of calculated equilibrium degassing trajectories (Fig. 4).

Glasses decompressed under variable rates to $25 \mathrm{MPa} \mathrm{P}_{\text {fin }}$ also show systematic deviations from the $25 \mathrm{MPa}$ isobar and calculated closed-system decompression paths, except glass 12-1 if error bars are considered (Fig. 5). They have $\mathrm{H}_{2} \mathrm{O}$ concentrations between 1.14 and $1.57 \mathrm{wt} \%$ and $\mathrm{CO}_{2}$ concentrations from 257 to $420 \mathrm{ppm}$ (Table 3). For comparison, volatile concentrations calculated for pre-decompression melt S5 assuming closed-system equilibrium degassing are respectively $1.56 \mathrm{wt} \% \mathrm{H}_{2} \mathrm{O}$ and $6 \mathrm{ppm} \mathrm{CO}_{2}$ at $25 \mathrm{MPa}$. The data also reveal that the $\mathrm{CO}_{2} / \mathrm{H}_{2} \mathrm{O}$ ratio of post-and pre-decompression melts are positively correlated, the starting melts with the highest $\mathrm{CO}_{2}$ yielding the most $\mathrm{CO}_{2}$-rich final melts (Fig. 5).

Decoupling between $\mathrm{H}_{2} \mathrm{O}$ and $\mathrm{CO}_{2}$

A closer analysis reveals that the behaviour of $\mathrm{H}_{2} \mathrm{O}$ and $\mathrm{CO}_{2}$ is actually decoupled. Final $\mathrm{H}_{2} \mathrm{O}$ and $\mathrm{CO}_{2}$ concentrations in glass are plotted as a function of sample vesicularities in Fig. 6. The data are compared with $\mathrm{H}_{2} \mathrm{O}$ and $\mathrm{CO}_{2}$ solubilities calculated at 50 and $25 \mathrm{MPa}$ for $\mathrm{H}_{2} \mathrm{O}-$ 
$\mathrm{CO}_{2}$ fluids of compositions selected to be at equilibrium with the melts. Molar $\mathrm{H}_{2} \mathrm{O} /\left(\mathrm{H}_{2} \mathrm{O}+\right.$ $\left.\mathrm{CO}_{2}\right)$ of fluids $\left(\mathrm{XH}_{2} \mathrm{O}\right.$ fl. $)$ coexisting at equilibrium with PST-9 melts at various pressures are known experimentally; below $100 \mathrm{MPa}$, they range between 0.8 and 0.85 (Pichavant et al. 2009, their figure 5). So, the solubility calculations have been performed for $\mathrm{XH}_{2} \mathrm{O}$ fl. $=0.8$ at $50 \mathrm{MPa}$ and 0.85 at $25 \mathrm{MPa}$. For both $\mathrm{P}_{\text {fin }}=50$ and $25 \mathrm{MPa}$, glass $\mathrm{H}_{2} \mathrm{O}$ concentrations show no dependence with vesicularity, the data for $25 \mathrm{MPa}$ including both constant and variable decompression charges (Fig. 6a). In addition, $\mathrm{H}_{2} \mathrm{O}$ concentrations of postdecompression glasses show close agreement with solubilities $\left(2.15\right.$ and $1.41 \mathrm{wt} \% \mathrm{H}_{2} \mathrm{O}$ respectively at 50 and $25 \mathrm{MPa}$ ) especially if one notes that $\mathrm{P}_{\text {fin }}$ are in fact $<50 \mathrm{MPa}$ for the “50 MPa” charges R1 and R4 (Table 2).

In contrast, post-decompression glass $\mathrm{CO}_{2}$ concentrations vary inversely with vesicularity (Fig. 6b). The constant decompression charges to $\mathrm{P}_{\text {fin }}=50 \mathrm{MPa}$ have glass $\mathrm{CO}_{2}$ concentrations negatively correlated with vesicularities up to $\sim 5 \%$. Their $\mathrm{CO}_{2}$ concentrations largely exceed the calculated solubility (71 ppm at $50 \mathrm{MPa})$, by up to nearly one order of magnitude. The variable decompression charges to $\mathrm{P}_{\text {fin }}=25 \mathrm{MPa}$ plot in the same part of the diagram and their $\mathrm{CO}_{2}$ concentrations are up to > one order of magnitude higher than the calculated solubility (24 ppm at $25 \mathrm{MPa}$ ). When vesicularity increases beyond $5 \mathrm{vol} \%$ (constant decompression charges to $\mathrm{P}_{\text {fin }}=25 \mathrm{MPa}$ ), glass $\mathrm{CO}_{2}$ concentrations drop to values ranging from $\leq 50 \mathrm{ppm}$ to $100 \mathrm{ppm}$. These $\mathrm{CO}_{2}$ concentrations are in agreement (within error) or slightly higher than the calculated $25 \mathrm{MPa}$ solubility, indicating a close approach toward equilibrium degassing.

$\mathrm{CO}_{2}$ is not homogeneously distributed in the $\mathrm{CO}_{2}$-rich glasses. FTIR profiles and maps performed on two $25 \mathrm{MPa} \mathrm{P}_{\text {fin }}$ variable decompression rate glasses $(\mathrm{R} 14, \mathrm{R} 15)$ show that the spatial distribution of $\mathrm{CO}_{2}$ in glass is controlled by the proximity to the gas-melt interface. $\mathrm{H}_{2} \mathrm{O}$ stays constant but $\mathrm{CO}_{2}$ is depleted and so $\mathrm{H}_{2} \mathrm{O} / \mathrm{CO}_{2}$ increases near the 
interface (Fig. 7). The $\mathrm{CO}_{2}$ concentration gradient is observed over distances of 100-200 $\mu \mathrm{m}$ in the melt. This is in reasonable agreement with distances calculated for $\mathrm{CO}_{2}$ diffusion in hydrous basaltic melt under our experimental conditions $\left(200-400 \mu \mathrm{m}, \mathrm{CO}_{2}\right.$ diffusivity calculated from Zhang and Ni 2010), suggesting that the near-interface concentration gradient reflects frozen diffusive motion of $\mathrm{CO}_{2}$ within the melt. The absence of $\mathrm{H}_{2} \mathrm{O}$ concentration gradient is the consequence of the $\mathrm{H}_{2} \mathrm{O}$ diffusivity being greater than the $\mathrm{CO}_{2}$ diffusivity in basaltic melts (Zhang and Stolper 1991). In addition to the $\mathrm{CO}_{2}$ spatial heterogeneity, the high $\mathrm{CO}_{2}$ standard deviations in glasses 4-3 and 12-1 (both starting from pumice) probably reflect initial $\mathrm{CO}_{2}$ heterogeneity in pre-decompression melts. This is because, in those experiments, the melt synthesis step (which is directly followed by decompression) is relatively short and so pre-decompression melts did not have long enough times to equilibrate.

\section{Interpretation and discussion of experimental observations}

Bubble nucleation in basaltic melts
Although our experiments were not designed specifically to study bubble nucleation in basaltic melts, they provide useful data on this topic critical for magma degassing. So far, systematics of bubble nucleation in silicate melts have concerned mostly rhyolitic melts (Mangan and Sisson 2000; Mourtada-Bonnefoi and Laporte 2002; 2004). Dacitic (Mangan and Sisson 2005; Gardner and Ketcham 2011) and rhyodacitic (Nowak et al. 2011) melts have also been investigated. During decompression, volatile supersaturation builds up in the melt; surface tension forces are overcome and bubbles homogeneously nucleate (Mangan and 
Sisson 2000; Mourtada-Bonnefoi and Laporte 2002; 2004). In some cases, the spatial interaction between growing bubbles can lead to their coalescence (Bai et al. 2007).

In the constant rate decompression experiments, neither the composition of predecompression melts $\left(\mathrm{CO}_{2} / \mathrm{H}_{2} \mathrm{O}\right.$ ratio) nor the decompression rate, from $0.26 \mathrm{~m} / \mathrm{s}(\mathrm{R} 16)$, $0.64 \mathrm{~m} / \mathrm{s}$ (R1, R10) to $1.03 \mathrm{~m} / \mathrm{s}$ (R4, R5, Table 2) strongly influences vesicularity. Previous work has shown that the decompression rate has little influence on critical bubble supersaturation pressures $\Delta \mathrm{P}_{\mathrm{s}}\left(=\mathrm{P}_{\mathrm{sat}}-\mathrm{P}_{\mathrm{hbn}}\right.$, with $\mathrm{P}_{\mathrm{sat}}=$ pressure of fluid saturation, here assumed to be $\leq \mathrm{P}_{\text {init }}$, and $\mathrm{P}_{\mathrm{hbn}}=$ maximum $\mathrm{P}_{\text {fin }}$ at which homogeneous bubble nucleation is observed, Mourtada-Bonnefoi and Laporte 2002; 2004), and our experiments do not reveal any large influence of $\mathrm{v}_{\mathrm{ramp}}$ either. As expected, the main variable controlling vesicularity is $\mathrm{P}_{\text {fin. }}$. Charges decompressed to $50 \mathrm{MPa} \mathrm{P}_{\text {fin }}$ have small bubbles and thus low vesicularities, $<5$ vol\% (Tables 2, 4). In contrast, charges decompressed to $25 \mathrm{MPa}$ show a marked vesicularity increase (vol\% bubbles up to 20\%) mainly accommodated by a large increase in bubble size (Tables 2, 4). Bubble number densities are in the same range or decrease slightly from 50 to $25 \mathrm{MPa} \mathrm{P}_{\text {fin }}$ (Table 4). Textural evidence thus suggests that homogeneous bubble nucleation takes place both at 50 and $25 \mathrm{MPa} \mathrm{P}_{\text {fin }}$ in the constant decompression rate experiments. Therefore, critical bubble supersaturation pressures of $150 \mathrm{MPa}$ maximum are inferred for the $\mathrm{H}_{2} \mathrm{O}$ - and $\mathrm{CO}_{2}$-bearing basaltic melts of this study. For rhyolitic (MourtadaBonnefoi and Laporte 2002) and dacitic (Mangan and Sisson 2005; Gardner and Ketcham 2011) melts, $\Delta \mathrm{P}_{\mathrm{s}}$ are respectively in the same range and lower than found here. Lensky et al. (2006) determined a critical supersaturation pressure of $200 \pm 100 \mathrm{MPa}$ for $\mathrm{CO}_{2}$ bubbles in a synthetic mafic melt decompressed from 1.5 GPa. From our results, an upper limit for the melt surface tension $(\sigma)$ of $0.18 \mathrm{~N} / \mathrm{m}$ is obtained using data from Table 4 to compute nucleation rates (see Mourtada-Bonnefoi and Laporte 2004; Mangan and Sisson 2005; Gardner and Ketcham 2011 for surface tension calculations). For comparison, $\sigma$ from 0.1 to 
$0.4 \mathrm{~N} / \mathrm{m}$ have been determined for basaltic melts (Khitarov et al. 1979), the lowest end of the range corresponding to hydrous compositions at $1200^{\circ} \mathrm{C}$.

The variable rate experiments decompressed to $25 \mathrm{MPa} \mathrm{P}_{\text {fin }}$ lack the large bubbles typical of the constant rate experiments for the same $\mathrm{P}_{\text {fin }}$. Their vesicularities (0-4 vol\%) are in the same range as in the constant rate experiments to $50 \mathrm{MPa} \mathrm{P}_{\text {fin }}(0-5$ vol\%, Table 2$)$. Thus, bubble growth did not take place between 50 and $25 \mathrm{MPa}$ (i.e. during ramp 2) in these experiments. Upon decompression, transfer of volatiles out of the melt occurs at the gas-melt interface (diffusive volatile transfer). This buffers the degree of volatile supersaturation in the melt and delays bubble nucleation (Mangan and Sisson 2000). Bubble growth is prevented and previously-formed bubbles may resorb (Yoshimura and Nakamura 2010). In our variable rate decompression experiments, diffusive volatile transport toward the gas-melt interface is demonstrated by the spatial distributions of $\mathrm{H}_{2} \mathrm{O}$ and $\mathrm{CO}_{2}$ (Fig. 7). The variable rate experiments have the lowest $\mathrm{v}_{\text {ramp2 }}$ and, consequently, the longest ramps $2\left(\mathrm{t}_{\mathrm{ramp} 2} \geq 1860 \mathrm{~s}\right.$, Table 2). Therefore, timescales for ramp 2-related diffusive volatile transfer are longer in the variable than in the constant rate experiments, explaining why bubble growth is preferentially delayed in the former than in the latter.

Another factor of difference between the variable and constant rate experiments is compositional. High $\mathrm{CO}_{2}$ melt concentrations negatively influence bubble nucleation (Bottinga and Javoy 1990b; Mourtada-Bonnefoi and Laporte 2002; Bai et al. 2007). Variations of $\mathrm{CO}_{2} / \mathrm{H}_{2} \mathrm{O}$ ratios between pre- and post-decompression glasses indicate that $\mathrm{CO}_{2}$ is kept in greater amounts within the melt in the variable than in the constant rate experiments. Short $t_{\text {ramp1 }}$ limits diffusive loss of $\mathrm{CO}_{2}$ out of the melt during ramp 1. This, together with the use of pre-decompression melts with high $\mathrm{CO}_{2} / \mathrm{H}_{2} \mathrm{O}$, would inhibit bubble nucleation during decompression. This is illustrated by experiments R14 and R15 (short $\mathrm{t}_{\mathrm{ramp} 1},<5000 \mathrm{~s}$, pre-decompression melt S5 which has the highest $\mathrm{CO}_{2} / \mathrm{H}_{2} \mathrm{O}$, Tables 1-2) 
which did not nucleate bubbles at $25 \mathrm{MPa} \mathrm{P}_{\text {fin }}$. It is concluded that certain mechanisms act cooperatively to inhibit bubble nucleation and growth during decompression; in particular, the variable rate experiments combine P-t trajectories, ramp durations and initial melt $\mathrm{CO}_{2} /$ $\mathrm{H}_{2} \mathrm{O}$ that promote $\mathrm{CO}_{2}$ retention within the melt during ramp 1 and volatile transfer out of the melt during ramp 2.

Degassing mechanisms

Our experiments simulate the degassing of $\mathrm{H}_{2} \mathrm{O}$ - and $\mathrm{CO}_{2}$-bearing basaltic melts as a result of decompression at essentially constant temperature. One important observation is that volatile concentrations of post-decompression glasses and vesicularities of experimental charges are correlated (Fig. 6). Therefore, magma vesiculation controls the degassing process and two end-member cases can be distinguished. In experiments decompressed at constant rate to 25 MPa (R5, R10, Table 2), homogeneous bubble nucleation takes place. Vesicularities of postdecompression charges are high (> 5\%) since bubbles are relatively large (Table 4). $\mathrm{CO}_{2}$ and $\mathrm{H}_{2} \mathrm{O}$ concentrations in post-decompression glasses approach their respective solubilities (Fig. 6). Because of the relatively large gas bubbles and high vesicularities, diffusive transfer of $\mathrm{H}_{2} \mathrm{O}$ and $\mathrm{CO}_{2}$ in the melt plays a negligible role. Therefore, a degassing regime controlled by the equilibrium partitioning of $\mathrm{CO}_{2}$ and $\mathrm{H}_{2} \mathrm{O}$ between melt and gas bubbles is generated and gas-melt equilibrium is approached. This is the situation classically considered in the volcanological literature (Sparks et al. 1994).

Another case is illustrated by variable rate decompression experiments to $25 \mathrm{MPa}$, especially R14 and R15 (Table 2). Because of inhibited bubble nucleation and growth due to the combination of specific P-t ascent trajectories, volatile transfer out of the melt and high $\mathrm{CO}_{2} / \mathrm{H}_{2} \mathrm{O}$ pre-decompression melts, homogeneous melt nucleation does not occur in those 
charges. Degassing thus proceeds by diffusive motion of volatiles over long distances in the melt and their loss at gas-melt interfaces (Mangan and Sisson 2000). Volatile diffusivities, but also durations of decompression ramps and sizes of experimental charges, control whether diffusive volatile motion is effective at the scale of the entire charge or is only local. For $\mathrm{H}_{2} \mathrm{O}$, concentrations in post-decompression glasses show no variation with vesicularity and are in good agreement with the solubilities (Fig. 6a). This suggests that melt $\mathrm{H}_{2} \mathrm{O}$ concentrations imposed by gas-melt interface equilibrium can propagate diffusively in the whole charge for our particular experimental durations and sample sizes. However, for $\mathrm{CO}_{2}$, concentrations largely exceeding the solubilities are obtained (Fig. 6b). $\mathrm{CO}_{2}$ concentration gradients are present near the gas-melt interface, reflecting diffusive motion of $\mathrm{CO}_{2}$ in the melt driven by gas-melt interface equilibrium (Fig. 7). Away from gas-melt interfaces, local $\mathrm{CO}_{2}$ concentrations higher than equilibrium values persist in the melt, generating a disequilibrium degassing trend (Mangan and Sisson 2000). In this regime, the behaviour of $\mathrm{H}_{2} \mathrm{O}$ and $\mathrm{CO}_{2}$ is effectively decoupled, reflecting the difference in melt diffusivity between the two volatile components. $\mathrm{H}_{2} \mathrm{O}$ diffuses faster than $\mathrm{CO}_{2}$ in hydrous basaltic melts (7-10 times faster, Zhang and Stolper 1991) and this translates directly into the contrasted behaviour of $\mathrm{H}_{2} \mathrm{O}$ and $\mathrm{CO}_{2}$ illustrated in Fig. 6. Kinetic effects similar to found here for $\mathrm{CO}_{2}$ are anticipated for volatiles with diffusivities significantly smaller than $\mathrm{H}_{2} \mathrm{O}$, such as $\mathrm{SO}_{2}$ (Baker et al. 2005).

The interpretation of our experimental observations can be generalized by considering volatile transfer distances in the melt. In the first end-member case above (constant rate decompressions to $25 \mathrm{MPa}$ ), bubbles have large sizes and so distances between them are small. Consequently, diffusive volatile transfer in the melt is necessarily limited by these short distances. In the second end-member case (variable rate charges R14 and R15 to 25 $\mathrm{MPa}$ ), bubbles are absent and so volatile transfer distances are long, being limited by sizes of 
experimental samples and lengths of volatile diffusion. The intermediate case includes the constant rate experiments to $50 \mathrm{MPa}(\mathrm{R} 1, \mathrm{R} 4, \mathrm{R} 16)$ and variable rate experiments to $25 \mathrm{MPa}$ (R12, R13, Table 2). In those experiments, homogeneous bubble nucleation takes place but the bubbles have small sizes (Table 4), implying intermediate bubble-bubble distances. So, in these charges, the evaluation of volatile transfer distances requires comparison between distances between bubbles and lengths of volatile diffusion. For $\mathrm{H}_{2} \mathrm{O}$, the data (Fig. 6a) confirm that diffusive equilibration can take place over relatively long distances. For $\mathrm{CO}_{2}$, concentrations higher than equilibrium persist in the melt (Fig. 6b), indicating that $\mathrm{CO}_{2}$ diffuses over distances smaller than distances between bubbles. As a general conclusion, we suggest that the degassing process, equilibrium vs. disequilibrium, is controlled by two characteristic distances, (1) the distance either between bubbles or to gas-melt interfaces, hereafter designated as the gas interface distance, and (2) the volatile diffusion distance (Fig. 8). The former depends on textural characteristics (presence and size of gas bubbles) imposed by the bubble nucleation and growth steps and by the size of experimental samples. The latter is controlled by the diffusivities of $\mathrm{H}_{2} \mathrm{O}$ and $\mathrm{CO}_{2}$ in the melt and experimental durations. Equilibrium degassing takes place when the gas interface distance is shorter than diffusion distances for both $\mathrm{H}_{2} \mathrm{O}$ and $\mathrm{CO}_{2}$. In the opposite case (gas interface distance longer than the diffusion distance for the slowest diffusing volatile, $\mathrm{CO}_{2}$ ), disequilibrium degassing will follow.

\section{Volcanological implications}

\section{General}


Our decompression experiments were scaled against a reference volcano (Stromboli), and so the results are considered applicable to the ascent, decompression and degassing of basaltic magmas. Probably the most important implication for volcanology is the demonstration of the possibility of disequilibrium degassing for temperatures, decompressions, ascent rates and melt compositions typical of a natural system. Future interpretations of gas data at basaltic volcanoes should take this possibility into consideration. Volcanic gas compositions are classically interpreted assuming gas-melt equilibrium. For example, variations in measured gas $\mathrm{H}_{2} \mathrm{O} / \mathrm{CO}_{2}$ ratios at Stromboli have been interpreted to reflect changes in the depth of explosive gas-melt segregation in the conduit (Burton et al. 2007). However, this study shows that degassing regimes are influenced in a complex way by decompression parameters $\left(\mathrm{P}_{\text {fin }}\right.$, P-t ascent trajectories and durations), pre-decompression melt $\mathrm{CO}_{2} / \mathrm{H}_{2} \mathrm{O}$ ratios and volatile diffusivities. Consequently, gas composition should carry information on magma ascent mechanisms and timescales. Although not analyzed in this study, the composition of the experimental gas phase is expected to vary along with the degassing mechanism. For ascent conditions allowing bubble nucleation and growth (experiments at constant rate to $25 \mathrm{MPa}$, R5, R10, Table 2), glass volatile concentrations suggest equilibrium partitioning of volatiles between melt and gas and, consequently, equilibrium gas compositions are expected. For ascent conditions where bubble nucleation is inhibited or bubble growth limited, the gas phase should be preferentially enriched in the volatile component with the highest melt diffusivity $\left(\mathrm{H}_{2} \mathrm{O}\right.$ in our experiments). This is because the melt phase keeps enrichment in the volatile component with the smallest diffusivity $\left(\mathrm{CO}_{2}\right.$ in our experiments). The same reasoning could be tested to interpret variations of gas $\mathrm{CO}_{2} / \mathrm{SO}_{2}$ ratios given the difference in diffusivity between these two components (Baker et al. 2005).

This study demonstrates that disequilibrium volatile degassing of basaltic magmas is the consequence of ascent conditions that either prevent gas bubbles to homogeneously 
nucleate (inhibited bubble nucleation) or limit their growth (limited bubble growth). In our experiments, conditions for inhibited bubble nucleation are encountered in the variable ascent rate experiments to $25 \mathrm{MPa} \mathrm{P}_{\text {fin }}$, especially those performed with $\mathrm{CO}_{2}$-rich predecompression melts. Conditions for limited bubble growth are found both under constant ascent rates to $\mathrm{P}_{\text {fin }}=50 \mathrm{MPa}$ and variable ascent rates to $\mathrm{P}_{\text {fin }}=25 \mathrm{MPa}$. Under those circumstances, degassing proceeds essentially by volatile transfer out of the melt, either at gas bubble or gas-melt interfaces. When gas interface distances are larger than volatile diffusion distances, degassing is kinetically limited by the diffusivities of the different volatiles in the melt. Thus, sizes, geometries and textures of magmatic flows (for example width of feeder dykes) should affect degassing processes. In contrast, when conditions are such that homogeneous bubble nucleation does occur, and bubbles can grow to large sizes (our experiments under constant ascent rates to $25 \mathrm{MPa} \mathrm{P}_{\text {fin }}$ ), degassing essentially follows equilibrium, i.e. volatile concentrations, both for the melt and the gas phase, can be modelled assuming gas-melt thermodynamic equilibrium (Moretti and Papale 2004; Papale et al. 2006; Allard 2010).

One important practical finding concerns the possibility to generate $\mathrm{CO}_{2}$ supersaturated melts during ascent and decompression of basaltic magmas. $\mathrm{CO}_{2}$-rich, $\mathrm{H}_{2} \mathrm{O}-$ poor melts that deviate from equilibrium degassing trajectories occur both as rapidly quenched basaltic flows at mid-ocean ridges (e.g. Dixon et al. 1988; Pineau and Javoy 1994; Saal et al. 2002; Aubaud et al. 2004 and references therein) and as glass inclusions in volcanic systems (e.g. Spilliaert et al. 2006; Collins et al. 2009; Helo et al. 2011). Such melt compositions exist at Stromboli, both as glass inclusions and embayments (Metrich et al. 2010). So far, these $\mathrm{CO}_{2}$-enriched melts have been explained by flushing of the system with $\mathrm{CO}_{2}$-rich gases (e.g. Blundy et al. 2010; Metrich et al. 2010; Pino et al. 2011). Here, we propose as an alternative possibility that such compositions represent $\mathrm{CO}_{2}$-oversaturated 
melts generated during magma ascent as a result of disequilibrium degassing. At Stromboli, both embayments and glass inclusions in scoriae keep high $\mathrm{CO}_{2}$ concentrations for relatively low $\mathrm{H}_{2} \mathrm{O},<2 \mathrm{wt} \%$ (Fig. 9). These compositions and the variable rate $25 \mathrm{MPa} \mathrm{P}_{\text {fin }}$ postdecompression experimental glasses partially overlap, consistent with the suggestion above about these natural glasses being generated as a result of disequilibrium degassing. However, the natural glasses have generally higher $\mathrm{CO}_{2}$ contents for a given $\mathrm{H}_{2} \mathrm{O}$ than the experimental glasses. Glass inclusions in pumices (representative of natural pre-decompression melts) also have $\mathrm{CO}_{2}$ concentrations higher than our pre-decompression melts (Fig. 9). Given the positive correlation between $\mathrm{CO}_{2} / \mathrm{H}_{2} \mathrm{O}$ in post-and pre-decompression melts (Fig. 5), postdecompression melts with $\mathrm{CO}_{2}$ concentrations more typical of Stromboli embayments and inclusions would be expected to be generated from pre-decompression melts slightly more $\mathrm{CO}_{2}$-rich and $\mathrm{H}_{2} \mathrm{O}$-poor than in this study.

\section{Stromboli}

Volcanic gas compositions before paroxysms at Stromboli are characterized by a dramatic increase of $\mathrm{CO}_{2}$ fluxes, this $\mathrm{CO}_{2}$-rich signal occurring over durations of typically several days before the eruption (Aiuppa et al. 2010b). Current models to explain these observations have appealed to the arrival of either a volatile-rich magma batch or a gas slug at shallow levels in the volcanic edifice (Metrich et al. 2010; Allard 2010). One difficulty with either model concerns the timescale of events, because the $\mathrm{CO}_{2}$ signal has durations much longer than needed for ascent of either magma or slug, constrained to $<10$ hours from petrological estimates (I Di Carlo, personal communication 2010). One possibility arising from our experimental simulations is that paroxysms at Stromboli are driven by explosive degassing and fragmentation of $\mathrm{CO}_{2}$-oversaturated melts. It should be noted that two of our variable rate 
decompression charges to $25 \mathrm{MPa} \mathrm{P}_{\text {fin }}$ yielded fragmented products. Although additional experiments are needed on this point, it is worth considering that the two fragmented charges come from the experiment with the shortest $t_{\text {ramp1 }}$ and the longest $t_{\text {ramp2 }}(R 11$, Table 2$)$ suggesting the possibility of specific fragmentation mechanisms for $\mathrm{CO}_{2}$-oversaturated melts.

In our model, the $\mathrm{CO}_{2}$ signal observed long before the paroxysmal eruption would be attributed to low pressure $(<50 \mathrm{MPa})$ degassing of $\mathrm{CO}_{2}$-oversaturated golden pumice magma batches. Direct evidence for the presence of such melts at Stromboli is provided by $\mathrm{CO}_{2^{-}}$ oversaturated glass inclusions and embayments (Fig. 9). Rather than a deep gas signal (Allard 2010; Metrich et al. 2010), we propose as a working hypothesis that the specific $\mathrm{CO}_{2}$-rich gas signature marks the degassing of $\mathrm{CO}_{2}$-oversaturated melts, and the preferential loss of "excess" $\mathrm{CO}_{2}$ dissolved in the melt. The long-term increase in $\mathrm{CO}_{2}$ fluxes before paroxysms would thus track the progressive arrival of $\mathrm{CO}_{2}$-oversaturated magmas in the shallow volcanic edifice and their low pressure degassing. Emplacement of a critical amount of supersaturated $\mathrm{CO}_{2}$-rich melts may provide the triggering factor leading to the paroxysmal eruption. The possibility to generate $\mathrm{CO}_{2}$-oversaturated melts offers new perspectives for fragmentation of mafic magmas and explosive basaltic volcanism.

\section{Conclusions}

Continuous decompression experiments have been performed on $\mathrm{H}_{2} \mathrm{O}$ - and $\mathrm{CO}_{2}$-bearing basaltic melts from $250-200$ to $50-25 \mathrm{MPa}$ at $1180-1140^{\circ} \mathrm{C}$. Melt volatile concentrations (2.7$3.8 \mathrm{wt} \% \mathrm{H}_{2} \mathrm{O}, 600-1300$ ppm $\left.\mathrm{CO}_{2}\right)$ and decompression parameters $\left(\mathrm{P}_{\text {init }}, \mathrm{P}_{\text {fin }}\right.$, $\mathrm{P}-\mathrm{t}$ trajectories, ramp durations) were scaled against a reference basaltic volcano, Stromboli (Aeolian islands, Italy). Ascent rates were varied from 0.25 to $\sim 1.5 \mathrm{~m} / \mathrm{s}$. Results directly simulate basaltic magma degassing and have implications for gas monitoring and explosive basaltic volcanism. 
They also stress the need for systematic experimental studies of (1) bubble nucleation and (2) volatile diffusion in basaltic melts and (3) degassing, vesiculation and fragmentation of $\mathrm{CO}_{2^{-}}$ oversaturated melts.

Textural characteristics of post-decompression charges (vesicularities, bubble numbers and sizes) and volatile concentrations of post-decompression glasses are closely correlated. Mechanisms of basaltic melt degassing depend on the capacity of the system to nucleate and grow gas bubbles. Constant rate decompression experiments suggest critical bubble supersaturation pressures of $150 \mathrm{MPa}$ maximum for the $\mathrm{H}_{2} \mathrm{O}$ - and $\mathrm{CO}_{2}$-bearing basaltic melts of this study. Bubble nucleation and growth are both inhibited in variable rate decompression experiments because $\mathrm{P}$-t ascent trajectories and initial melt $\mathrm{CO}_{2} / \mathrm{H}_{2} \mathrm{O}$ promote $\mathrm{CO}_{2}$ retention within the melt and diffusive volatile loss.

Both equilibrium and disequilibrium degassing occur in our experiments. The degassing process is controlled by two characteristic distances, the gas interface distance (distance either between bubbles or to gas-melt interfaces) and the volatile diffusion distance. Equilibrium degassing takes place when the gas interface distance is shorter than diffusion distances for both $\mathrm{H}_{2} \mathrm{O}$ and $\mathrm{CO}_{2}$. When the gas interface distance is longer than the diffusion distance for the slowest diffusing volatile $\left(\mathrm{CO}_{2}\right)$, disequilibrium degassing occurs; $\mathrm{CO}_{2}$ oversaturated melts and fluids more $\mathrm{H}_{2} \mathrm{O}$-rich than equilibrium compositions are generated.

Disequilibrium degassing can occur for temperatures, decompressions, ascent rates and melt compositions typical of basaltic systems, and interpretation of gas data at basaltic volcanoes should integrate this possibility. Fragmentation of $\mathrm{CO}_{2}$-oversaturated melts warrants more detailed consideration as a mechanism driving explosive basaltic volcanism.

Acknowledgements We thank A. Aiuppa, A. Bertagnini, S. Calvari, M. Pompilio and M. Ripepe for fruitful discussions. Detailed and constructive reviews by R. Brooker, J. Lowenstern and an anonymous reviewer, and the editorial work of M. Schmidt, have considerably improved the presentation of this study. This project has 
been financially supported by INGV and DPC (Project Paroxysm), by the University of Palermo, the Observatoire pour les Sciences de l'Univers en Région Centre (OSUC) and is part of the VUELCO (EC FP7) and DEGAZMAG (ANR Blanc) projects.

\section{References}

Aiuppa A, Bertagnini A, Metrich N, Moretti R, Di Muro A (2010a) A model of degassing for Stromboli volcano. Earth Planet Sci Lett 295: 195-204

Aiuppa A, Burton M, Caltabiano T, Giudice G, Guerrieri S, Liuzzo M, Murè F, Salerno G (2010b) Unusually large magmatic $\mathrm{CO}_{2}$ gas emissions prior to a basaltic paroxysm. Geophys Res Lett 37: L17303

Allard P (2010) $\mathrm{A} \mathrm{CO}_{2}$-rich gas trigger of explosive paroxysms at Stromboli basaltic volcano, Italy. J Volcanol Geotherm Res 189: 363-374

Aubaud C, Pineau F, Jambon A, Javoy M (2004) Kinetic disequilibrium of C, He, Ar and carbon isotopes during degassing of mid-ocean ridge basalts. Earth Planet Sci Lett 222: $391-406$

Bai L, Baker DR, Rivers (2007) Experimental study of bubble growth in Stromboli basalt melts at 1 atm. Earth Planet Sci Lett 267: 533-547

Baker DR, Freda C, Brooker RA, Scarlato P (2005) Volatile diffusion in silicate melts and its effects on melt inclusions. Annals Geophys 48: 699-717

Blundy J, Cashman KV, Rust A, Witham F (2010) A case for $\mathrm{CO}_{2}$-rich arc magmas. Earth Planet Sci Lett 290: 289-301

Bottinga Y, Javoy M (1990a) MORB degassing: bubble growth and ascent. Chem Geol 81: $255-270$

Bottinga Y, Javoy M (1990b) Mid-ocean ridge basalt degassing: bubble nucleation. J Geophys Res 95: 5125-5131 
Burton MR., Allard P, Muré F, La Spina A (2007) Magmatic gas composition reveals the source depth of slug-driven strombolian explosive activity. Science 37: 277-230

Cartigny P, Pineau F, Aubaud C, Javoy M (2008) Towards a consistent mantle carbon flux estimate: insights from volatile systematics $\left(\mathrm{H}_{2} \mathrm{O} / \mathrm{Ce}, \mathrm{D}, \mathrm{CO}_{2} / \mathrm{Nb}\right)$ in the north atlantic mantle. Earth Planet Sci Lett 265: 672-685

Collins SJ, Pyle DM, Maclennan J (2009) Melt inclusion track pre-eruption storage and dehydration of magmas at Etna. Geology 37: 571-574

Di Carlo I, Pichavant M, Rotolo SG, Scaillet B (2006) Experimental crystallization of a highK arc basalt: the golden pumice, Stromboli volcano (Italy). J Petrol 47: 1317-1343

Dixon JE, Stolper EM, Delaney JR (1988) Infrared spectroscopic measurements of $\mathrm{CO}_{2}$ and $\mathrm{H}_{2} \mathrm{O}$ in Juan de Fuca Ridge basaltic glasses. Earth Planet Sci Lett 90: 87-104

Dixon JE, Stolper EM, Holloway JR (1995) An experimental study of water and carbon dioxide solubilities in mid-ocean ridge basaltic liquids. Part I: calibration and solubility models. J Petrol 36: 1607-1631

Dixon JE, Stolper EM (1995) An experimental study of water and carbon dioxide solubilities in mid-ocean ridge basaltic liquids. Part II: applications to degassing. J Petrol 36: 16331646

Gardner JE, Ketcham RA (2011) Bubble nucleation in rhyolite and dacite melts: temperature dependence of surface tension. Contrib Mineral Petrol 162: 929-943

Head JW III, Wilson L (2003) Deep submarine pyroclastic eruptions: theory and predicted landforms and deposits. J Volc Geotherm Res 121: 155-193

Helo C, Longpré MA, Shimizu N, Clague DA, Stix J (2011) Explosive eruptions at midocean ridges driven by $\mathrm{CO}_{2}$-rich magmas. Nature Geosci 4: 260-263

Jaupart C, Vergniolle S (1988) Laboratory models of Hawaiian and Strombolian eruptions. Nature 331: 58-60 
Khitarov NI, Lebedev YB, Dorfman AM, Bagdasarov NS (1979) Effects of temperature, pressure and volatiles on the surface tension of molten basalt. Geochem Int 16: 78-86.

Landi P, Metrich N, Bertagnini A, Rosi M (2008) Recycling and "re-hydration" of degassed magma inducing transient dissolution/crystallization events at Stromboli (Italy). J Volc Geotherm Res 174: 325-336

Lensky NG, Niebo RW, Holloway JR, Lyakhovsky V, Navon O (2006) Bubble nucleation as a trigger for xenolith entrapment in mantle melts. Earth Planet Sci Lett 245: 278-288

Lesne P, Scaillet B, Pichavant M, Iacono-Marziano G, Bény J-M (2011a) The H2O solubility of alkali basaltic melts: an experimental study. Contrib Mineral Petrol 162: 133-151

Lesne P, Scaillet B, Pichavant M, Bény J-M (2011b) The carbon dioxide solubility in alkali basalts: an experimental study. Contrib Mineral Petrol 162: 153-168

Lesne P, Kohn SC, Blundy J, Witham F, Botcharnikov RE, Behrens H (2011c) Experimental simulation of closed-system degassing in the system basalt- $\mathrm{H}_{2} \mathrm{O}-\mathrm{CO}_{2}-\mathrm{S}-\mathrm{Cl}$. J Petrol 52: $1737-1762$

Mangan M, Sisson T (2000) Delayed, disequilibrium degassing in rhyolite magma: decompression experiments and implications for explosive volcanism. Earth Planet Sci Lett 183: 441-455

Mangan M, Sisson T (2005) Evolution of melt-vapor surface tension in silicic volcanic systems: experiments with hydrous melts. J Geophys Res 110: B01202 Metrich N, Bertagnini A, Di Muro A (2010) Conditions of magma storage, degassing and ascent at Stromboli: new insights into the volcanic plumbing system with inferences on the eruptive dynamics. J Petrol 51: 603-626

Moretti R, Papale P (2004) On the oxidation state and volatile behaviour in multicomponent gas-melt equilibria. Chem Geol 213: 265-280 
Mourtada-Bonnefoi CC, Laporte D (2002) Homogeneous bubble nucleation in rhyolitic magmas : an experimental study of the effect of $\mathrm{H}_{2} \mathrm{O}$ and $\mathrm{CO}_{2}$. J Geophys Res:107, B4, 2066, 10.1029/2001JB000290

Mourtada-Bonnefoi, CC, Laporte D (2004) Kinetics of bubble nucleation in a rhyolitic melt: an experimental study of the effect of ascent rate. Earth Planet Sci Lett 218: 521-537

Nowak M, Cichy S, Botcharnikov RE, Walker N, Hurkuck W (2011) A new type of highpressure low-flow metering valve for continuous decompression: first experimental results on degassing of rhyolitic melts. Am Mineral 96: 1373-1380

Papale P, Moretti R, Barbato D (2006) The compositional dependence of the saturation surface of $\mathrm{H}_{2} \mathrm{O}+\mathrm{CO}_{2}$ fluids in silicate melts. Chem Geol 229: 78-95

Pichavant M, Di Carlo I, Le Gac Y, Rotolo SG, Scaillet B (2009) Experimental constraints on the deep magma feeding system at Stromboli volcano, Italy. J Petrol 50: 601-624

Pichavant M, Pompilio M, D’Oriano C, Di Carlo I (2011) The deep feeding system of Stromboli, Italy: insights from a primitive golden pumice. Eur J Mineral 23: 499-517

Pineau F, Javoy M (1994) Strong degassing at ridge crests: the behaviour of dissolved carbon and water in basalt glasses at $14^{\circ} \mathrm{N}$, Mid-Atlantic Ridge. Earth Planet Sci Lett 123: 179198

Pino NA, Moretti R, Allard P, Boschi E (2011) Seismic precursors of a basaltic paroxysmal explosion track deep gas accumulation and slug upraise. J Geophys Res 116: B02313

Polacci M, Baker DR, Mancini L, Tromba G, Zanini F (2006) Three-dimensional investigation of volcanic textures by X-ray microtomography and implications for conduit processes. Geophys Res Lett: 33 L13312

Rosi M, Bertagnini A, Landi P (2000) Onset of the persistent activity at Stromboli volcano (Italy). Bull Volcanol 62: 294-300 
Saal AE, Hauri EH, Langmuir CH, Perfit MR (2002) Vapour undersaturation in primitive mid-ocean-ridge basalt and the volatile content of Earth's upper mantle. Nature 419: 451455

Shinohara H, Aiuppa A, Giudice G, Gurrieri S, Liuzzo M (2008) Variation of $\mathrm{H}_{2} \mathrm{O} / \mathrm{CO}_{2}$ and $\mathrm{CO}_{2} / \mathrm{SO}_{2}$ ratios of volcanic gases discharged by continuous degassing of Mount Etna volcano, Italy. J Geophys Res 113: B09203

Sparks RSJ, Barclay J, Jaupart C, Mader HM, Phillips JC (1994) Physical aspects of magmatic degassing I. Experimental and theoretical constraints on vesiculation. In: Carroll MR, Holloway JR (eds) Volatiles in Magmas. Mineralogical Society of America Reviews in Mineralogy 30, pp 413-445

Spilliaert N, Allard P, Metrich N, Sobolev AV (2006) Melt inclusion record of the conditions of ascent, degassing and extrusion of volatile-rich alkali basalt during the powerful 2002 flank eruption of Mount Etna (Italy). J Geophys Res 111: B04203

Suckale J, Hager BH, Elkins-Tanton LT, Nave J-C (2010) It takes three to tango : 2. Bubble dynamics in basaltic volcanoes and ramifications for modelling normal Strombolian activity. J Geophys Res 115: B07410

Vetere F, Behrens H, Misiti V, Ventura G, Holtz F, De Rosa R, Deubener J (2007) The viscosity of shoshonitic melts (Vulcanello Peninsula, Aeolian Islands, Italy): insights on the magma ascent in dykes. Chem Geol 245: 89-102

Yoshimura S, Nakamura M (2010) Chemically driven growth and resorption of bubbles in a multivolatile magmatic system. Chem Geol 276: 18-28

Zhang Y, Stolper EM (1991) Water diffusion in a basaltic melt. Nature 351: 306-309

Zhang Y, Ni H (2010) Diffusion of H, C, and O components in silicate melts. In: Zhang Y, Cherniak DJ (eds) Diffusion in Minerals and Melts. Mineralogical Society of America Reviews in Mineralogy 72, pp 171-225 


\section{Figure captions}

Fig. 1 Pressure-time diagrams showing decompression trajectories for (A) a representative constant decompression rate experiment (R16) and (B) a representative variable decompression rate experiment (R15). Actual pressure-time data points are plotted with an interval of $10 \mathrm{~s}$ between data acquisition. Ascent rates $\left(\mathrm{v}_{\mathrm{ramp}}\right)$, either constant (R16) or variable (R15) are indicated. R16 and R15 are two non-isothermal experiments. Temperature was varied linearly from 1180 to $1150^{\circ} \mathrm{C}$ along the decompression path. See Table 2 for more details. Notice the difference in experimental duration between (A) and (B).

Fig. 2 Composition photo-montage of post-decompression charge R1-2 showing typical texture of experimental products and bubble types. Photomicrographs taken under reflected light. $\mathrm{Au}_{80} \mathrm{Pd}_{20}$ : capsule material. Notice the large type 1 bubbles close to the capsule walls, the few large type 2 bubbles inside the glass and the small type 3 bubbles that are present locally. See text for interpretation of bubble types.

Fig. 3. Slice through X-ray microtomographic volume of charge R5-2 showing numerous homogeneously distributed bubbles inside the glass. Notice the difference in size between bubbles. The large type 2 bubble results from both diffusive bubble growth and coalescence. The smaller type 3 bubbles mark homogeneous bubble nucleation within the melt.

Fig. $4 \mathrm{H}_{2} \mathrm{O}$ and $\mathrm{CO}_{2}$ concentrations in glasses from the constant ascent/decompression rate experiments. Filled circles: pre-decompression glasses; filled squares: glasses decompressed to $50 \mathrm{MPa} \mathrm{P}_{\text {fin }}$; filled diamonds: glasses decompressed to $25 \mathrm{MPa} \mathrm{P}_{\text {fin }}$. For the pre- 
decompression glasses, colours refer to synthesis experiments S1, S2, S3, S5 in Table 1. For the post-decompression glasses, symbol colours specify the pre-decompression glasses used. $p$ indicates a charge starting from pumice instead of pre-synthesized glass, see text. Error bars (standard deviations, Table 3) are indicated on the data points. Thin continuous lines: fluidmelt equilibrium saturation isobars $(25,50,200,250 \mathrm{MPa})$; dashed curves: equilibrium decompression paths calculated for each pre-decompression melt assuming closed-system behaviour. All equilibrium fluid-melt calculations are performed with the model of Papale et al. (2006).

Fig. 5. $\mathrm{H}_{2} \mathrm{O}$ and $\mathrm{CO}_{2}$ concentrations in glasses from the variable ascent/decompression rate experiments. Filled circles: pre-decompression glasses; open diamonds: glasses decompressed to $25 \mathrm{MPa} \mathrm{P}_{\text {fin. }}$. For the pre-decompression glasses, colours refer to synthesis experiments S3, S4, S5 in Table 1. For the post-decompression glasses, symbol colours specify the pre-decompression glasses used. $p$ indicates a charge starting from pumice instead of pre-synthesized glass, see also text. Error bars (standard deviations, Table 3) are indicated on the data points. Thin continuous lines and dashed curves as in Fig. 4.

Fig. 6. $\mathrm{H}_{2} \mathrm{O}(\mathrm{A})$ and $\mathrm{CO}_{2}$ (B) concentrations in post-decompression glasses (Table 3) plotted as a function of vol\% bubbles in the charge (Table 2; 4). Data for both constant and variable ascent/decompression rate are shown. Same symbols as in Figs. 4 and 5. Dashed horizontal lines are solubilities calculated for fluids with $\mathrm{XH}_{2} \mathrm{O}\left(\right.$ molar $\left.\mathrm{H}_{2} \mathrm{O} /\left(\mathrm{H}_{2} \mathrm{O}+\mathrm{CO}_{2}\right)\right)$ of 0.80 and 0.85 at 50 and $25 \mathrm{MPa}$ respectively (see text). Error bars (standard deviations, Table 3) are indicated on the data points. 
Fig. 7. FTIR traverse and map performed on a glass wafer from charge R14 (Table 2). a: photomicrograph of the sample and location of traverse 1 and map. b: analytical results for traverse 1 . The bubble is located to the right of the profiles. Top: intensity of the $3530 \mathrm{~cm}^{-1}$ band (total water), intermediate: intensity of the $1515 \mathrm{~cm}^{-1}$ (carbonate), bottom: intensity ratio between the $3530 \mathrm{~cm}^{-1}$ and the $1515 \mathrm{~cm}^{-1}$ bands. Other traverses (not shown) have yielded identical results. c: volatile concentration map showing the spatial distribution of the 3530 $\mathrm{cm}^{-1} / 1515 \mathrm{~cm}^{-1}$ intensity ratio and the $\mathrm{CO}_{2}$-depleted rim around the bubble (located to the right of the map).

Fig. 8. Illustration of the degassing model discussed in text. (a) Schematic representation of experimental charges showing capsule, gas phase, gas-melt interfaces, basaltic melt and two gas bubbles present inside the melt. $\mathrm{M}$ represents a volume of $\mathrm{H}_{2} \mathrm{O}$ - and $\mathrm{CO}_{2}$-bearing basaltic melt experiencing degassing following decompression. M-b and M-g refer respectively to the half distance between bubbles and the distance to a gas-melt interface, as discussed in text. $\mathrm{dH}_{2} \mathrm{O}$ and $\mathrm{dCO}_{2}$ are the diffusion distances for $\mathrm{H}_{2} \mathrm{O}$ and $\mathrm{CO}_{2}$ in the melt. Diffusion is assumed spherical and diffusivities constant (but different between $\mathrm{H}_{2} \mathrm{O}$ and $\mathrm{CO}_{2}$ ). The diffusion distances are represented from $\mathrm{M}$ to allow comparison with the other distances M-b and M-g. The drawing illustrates one possible case of disequilibrium degassing which corresponds to most of our experimental charges. Bubbles nucleate during decompression but bubble growth is limited, yielding relatively large bubble-bubble distances. Degassing proceeds by diffusive volatile transfer in the melt towards gas bubbles and gas-melt interfaces. The drawing illustrates the case of the half distance between bubbles (and distance to the gas-melt interface) being longer than the $\mathrm{CO}_{2}$ volatile diffusion distance. Therefore, $\mathrm{CO}_{2}$ concentration $\left(\mathrm{CCO}_{2}\right)$ gradients are present in the melt, reflecting diffusive motion of $\mathrm{CO}_{2}$ driven by local equilibrium at the bubble-melt interfaces (b). Away from these interfaces, $\mathrm{CO}_{2}$ concentrations 
higher than solubilities persist in the melt (b). In comparison, for $\mathrm{H}_{2} \mathrm{O}$, the diffusion distance is longer than the distance between bubbles and to the gas-melt interfaces. $\mathrm{H}_{2} \mathrm{O}$ concentrations $\left(\mathrm{CH}_{2} \mathrm{O}\right)$ imposed by local equilibrium at bubble-melt and gas-melt interfaces can propagate diffusively in the whole charge as demonstrated in (b) by $\mathrm{CH}_{2} \mathrm{O}$ being equal to the solubility. A disequilibrium degassing trend is generated (c) with a melt phase enriched in the volatile component with the lowest diffusivity $\left(\mathrm{CO}_{2}\right.$ in our experiments $)$ and a gas phase in the volatile component with the highest diffusivity $\left(\mathrm{H}_{2} \mathrm{O}\right.$ in our experiments).

Fig. 9. $\mathrm{H}_{2} \mathrm{O}$ and $\mathrm{CO}_{2}$ concentrations in glasses from Stromboli and comparison with experimental glasses from this study. Error bars are omitted for clarity. Stromboli glasses plotted include glass inclusions from pumice (pumice mi) and scoriae (scoria mi), and embayments. Data from Metrich et al. (2010). Experimental glasses include pre- and postdecompression glasses (respectively Tables 1 and 3) from constant (50 $\mathrm{MPa} \mathrm{P}_{\text {fin }} ; 25 \mathrm{MPa} \mathrm{P}_{\text {fin }}$ ) and variable (var $25 \mathrm{MPa} \mathrm{P}_{\text {fin }}$ ) ascent rate experiments. Thin continuous lines as in Fig. 4. The dashed curve is the closed-system equilibrium decompression trajectory calculated for 2.4 wt $\% \mathrm{CO}_{2}$ in bulk magma (after Metrich et al. 2010). 

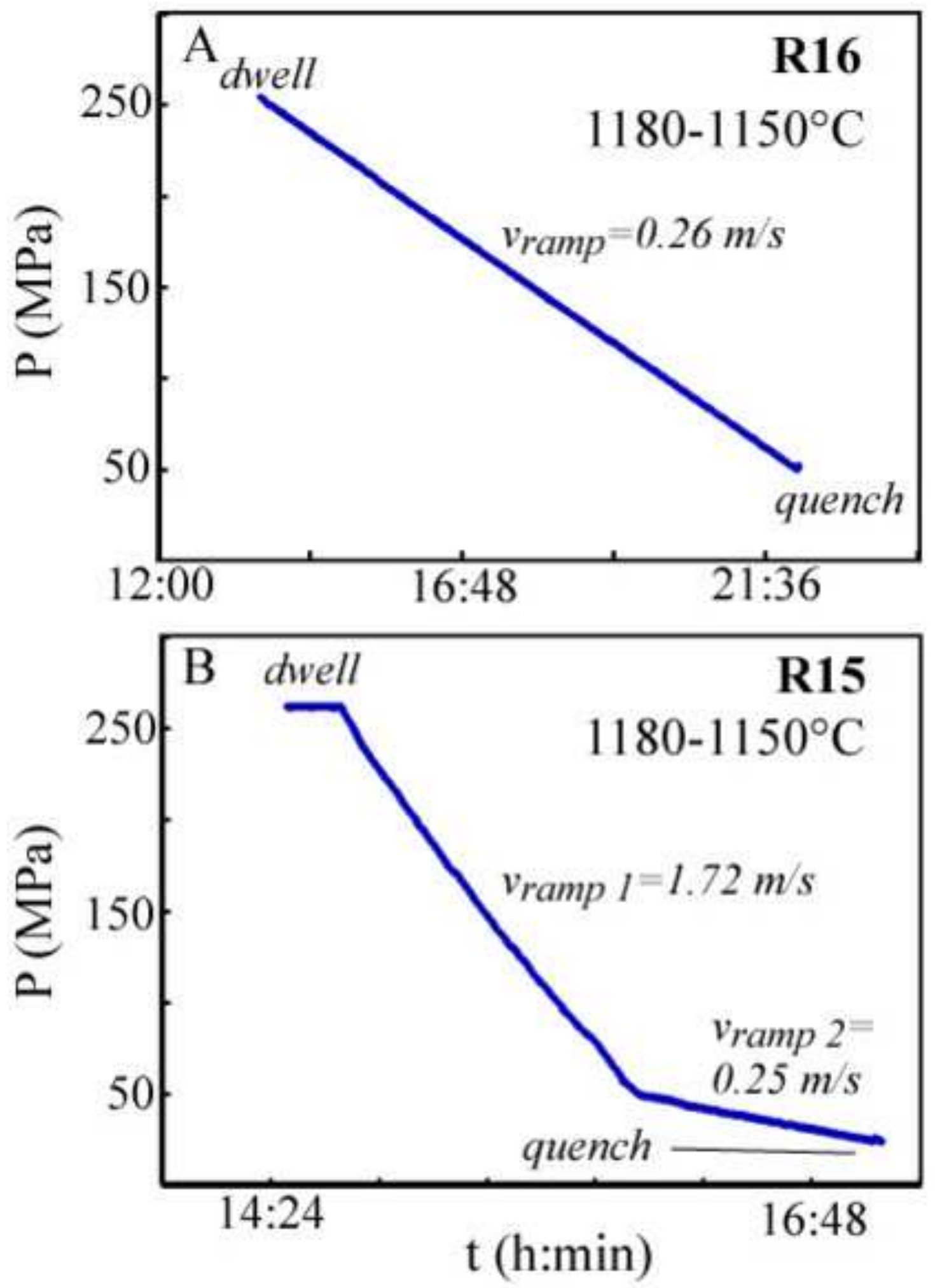

Pichavant et al. Fig. 1 


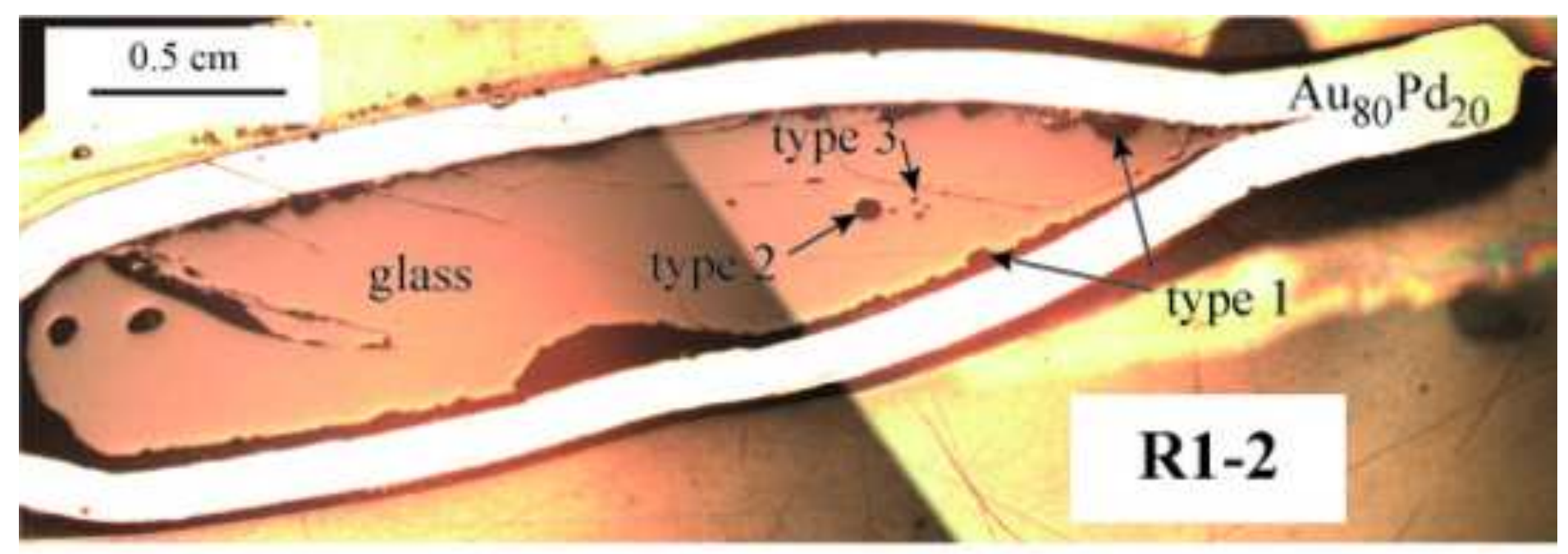

Pichavant et al. Fig. 2 


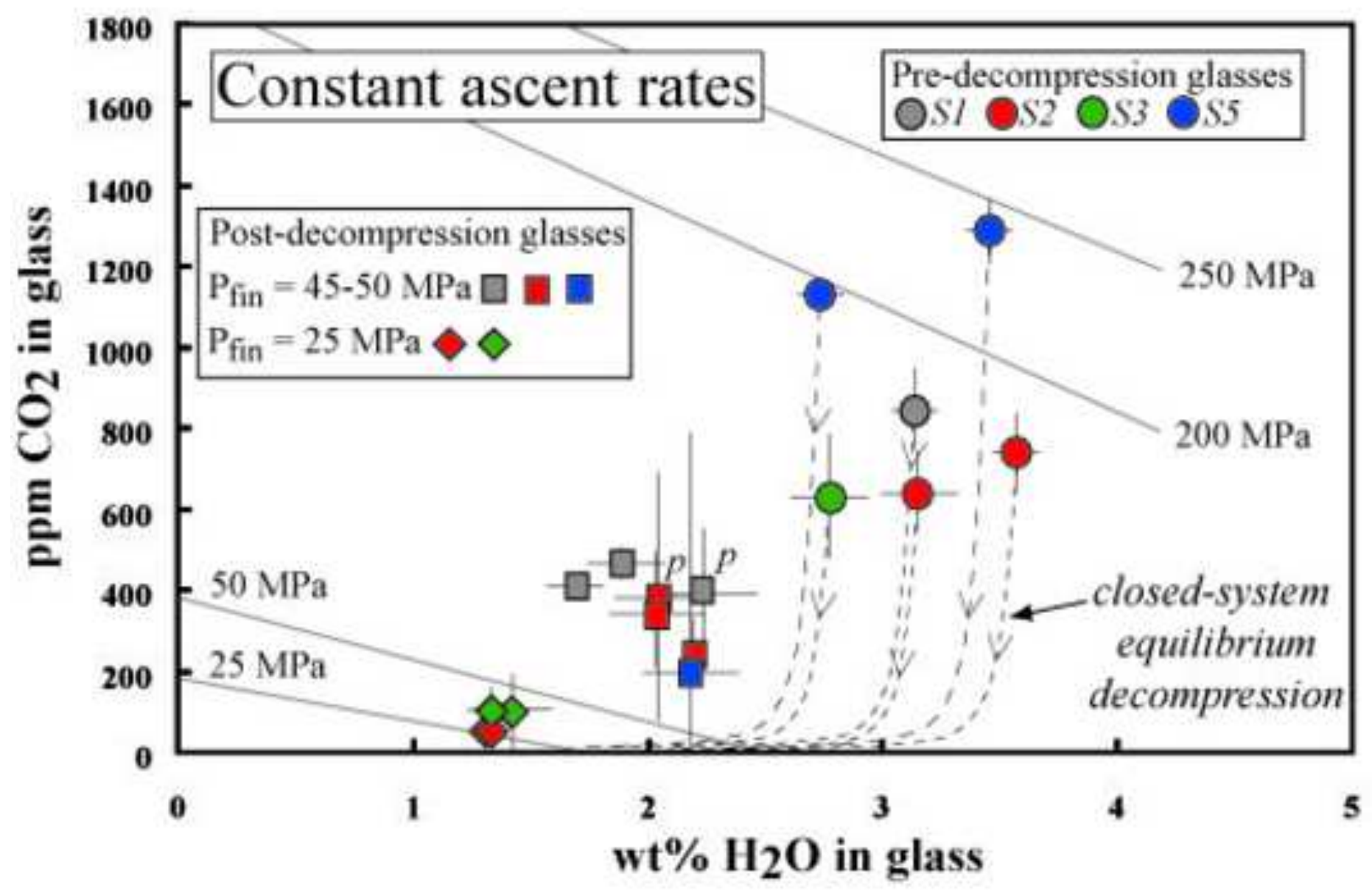

Pichavant et al. Fig. 4 


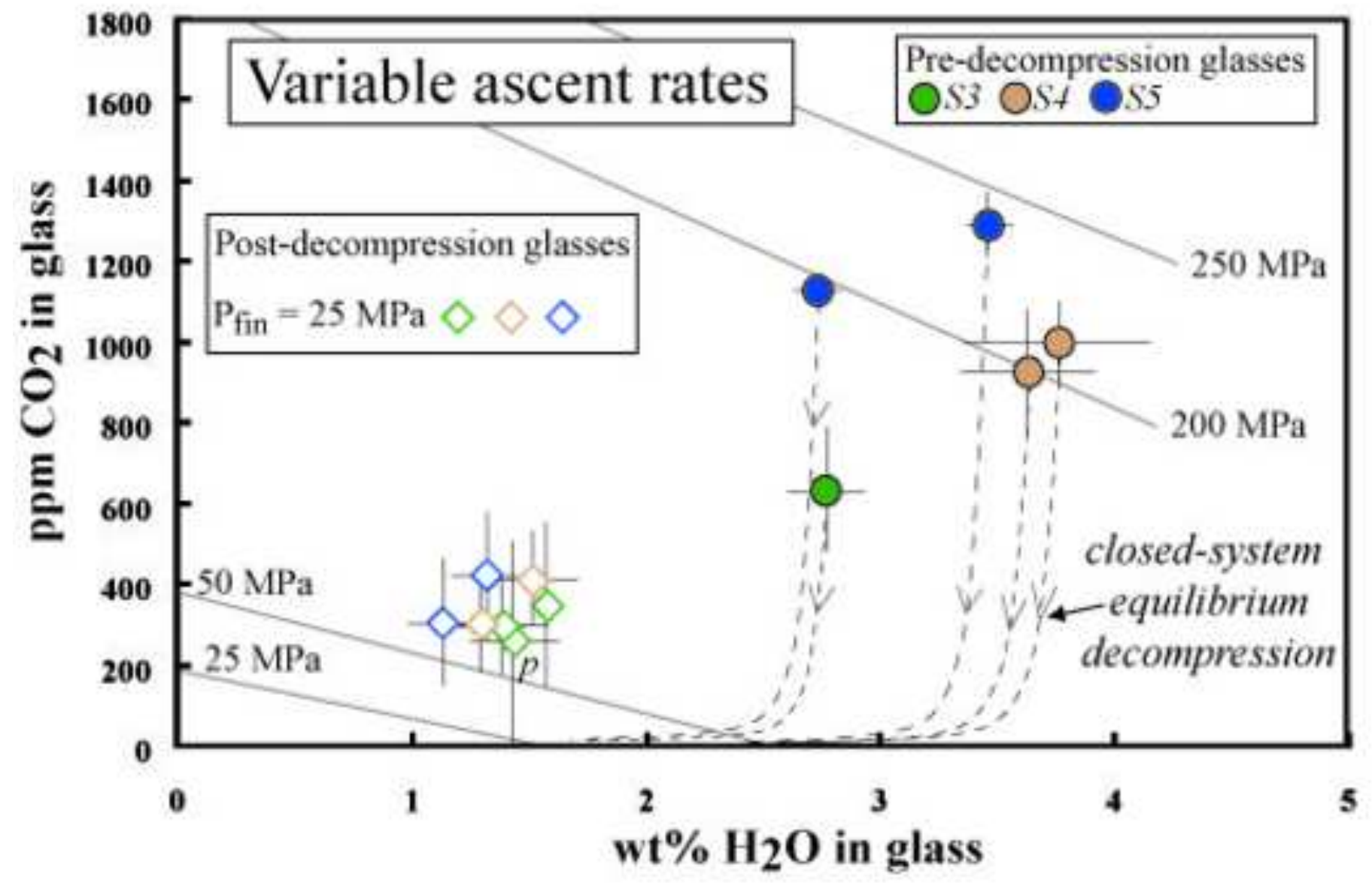

Pichavant et al. Fig. 5 
Variable ascent rates Constant ascent rates

$\mathrm{P}_{\mathrm{fin}}=45-50 \mathrm{MPa} \square \mathrm{a}$

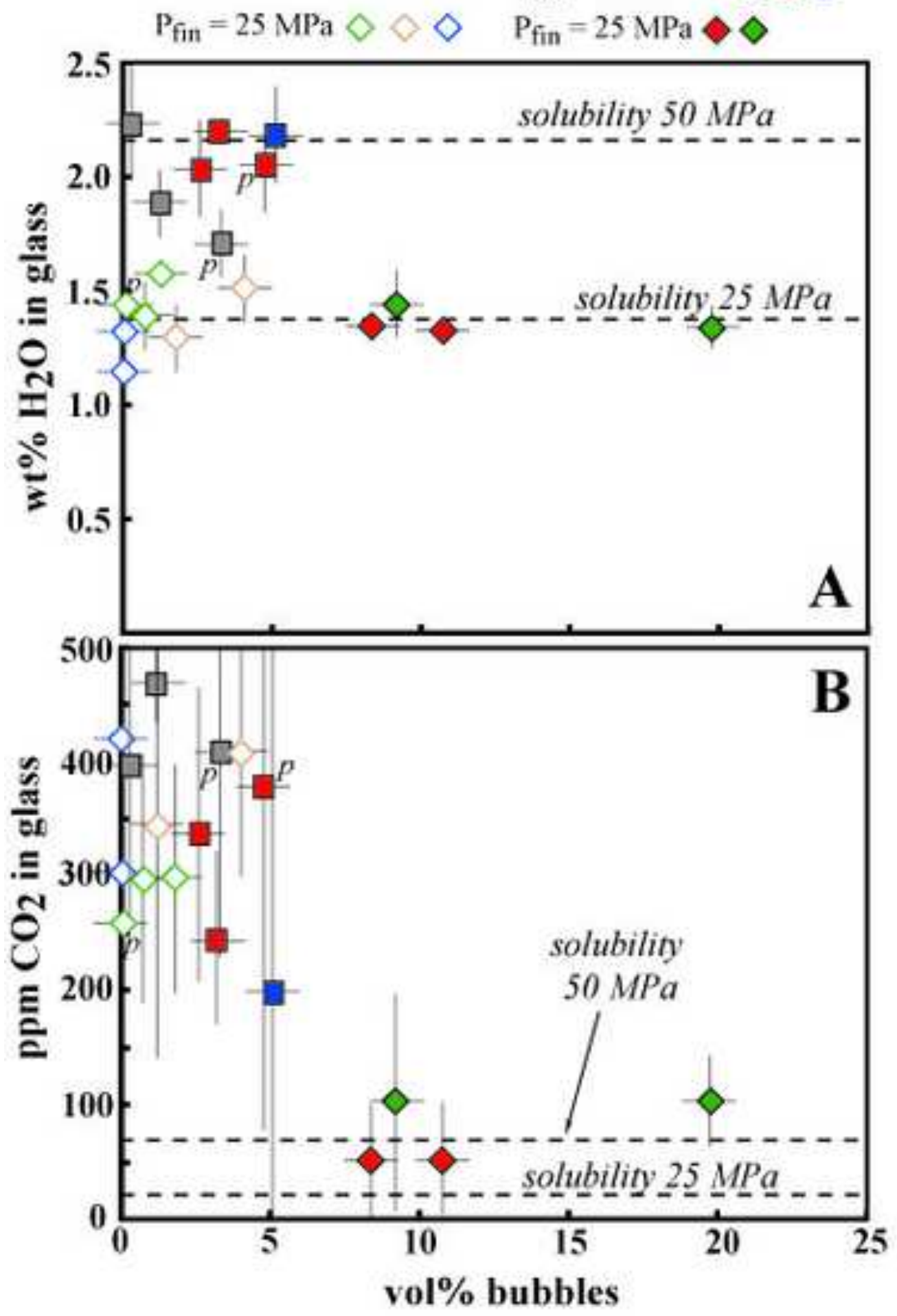

Pichavant et al. Fig. 6 


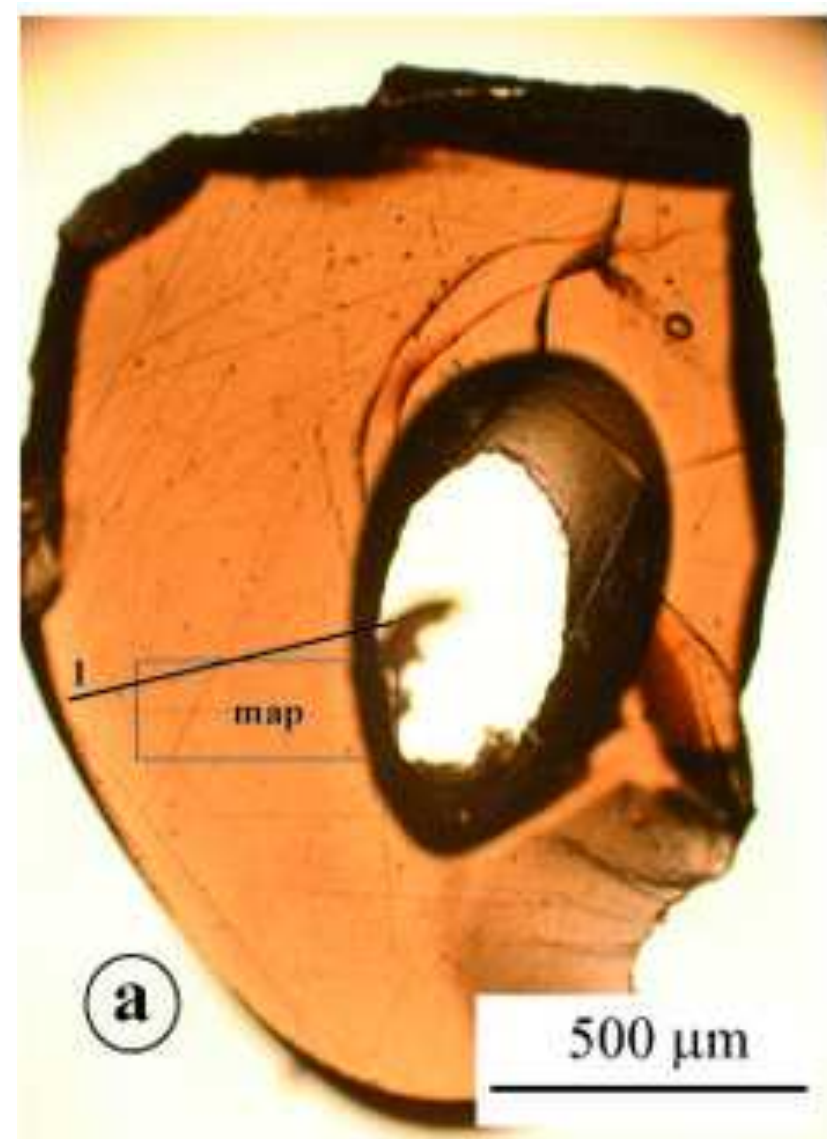

traverse 1
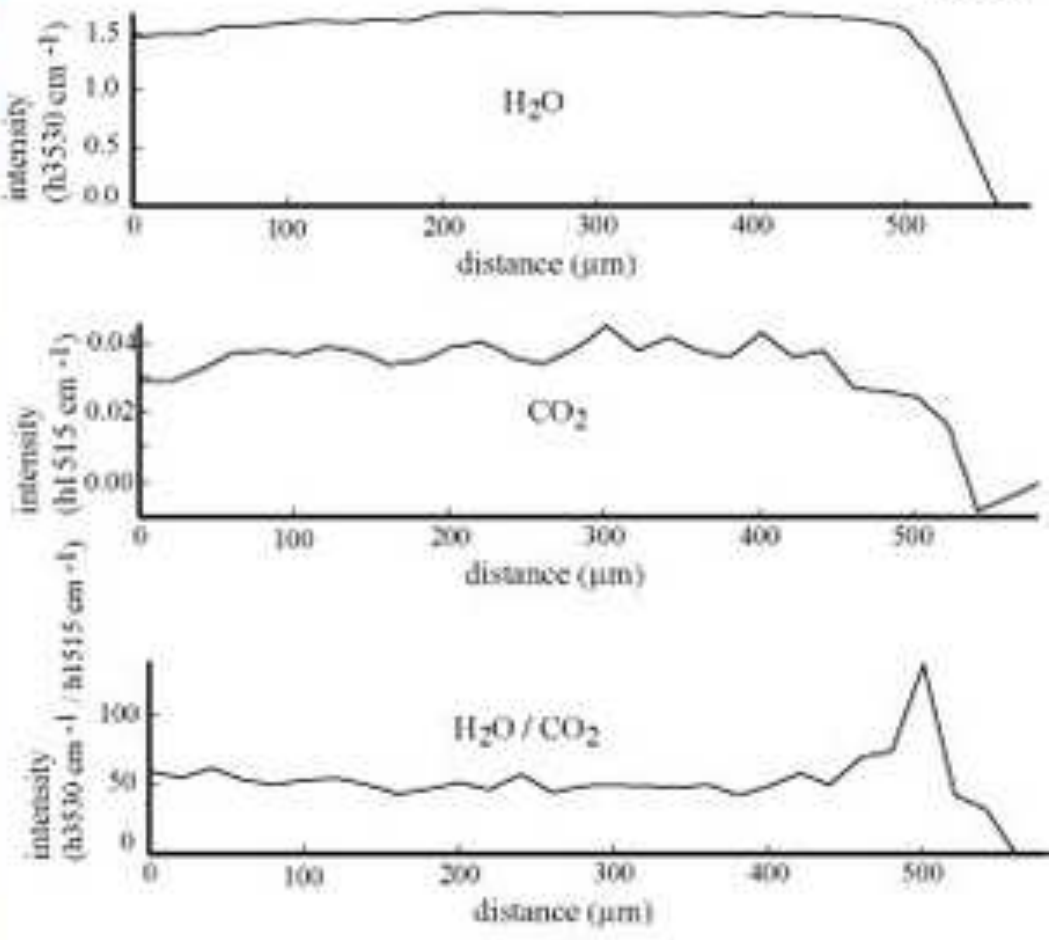

(c)

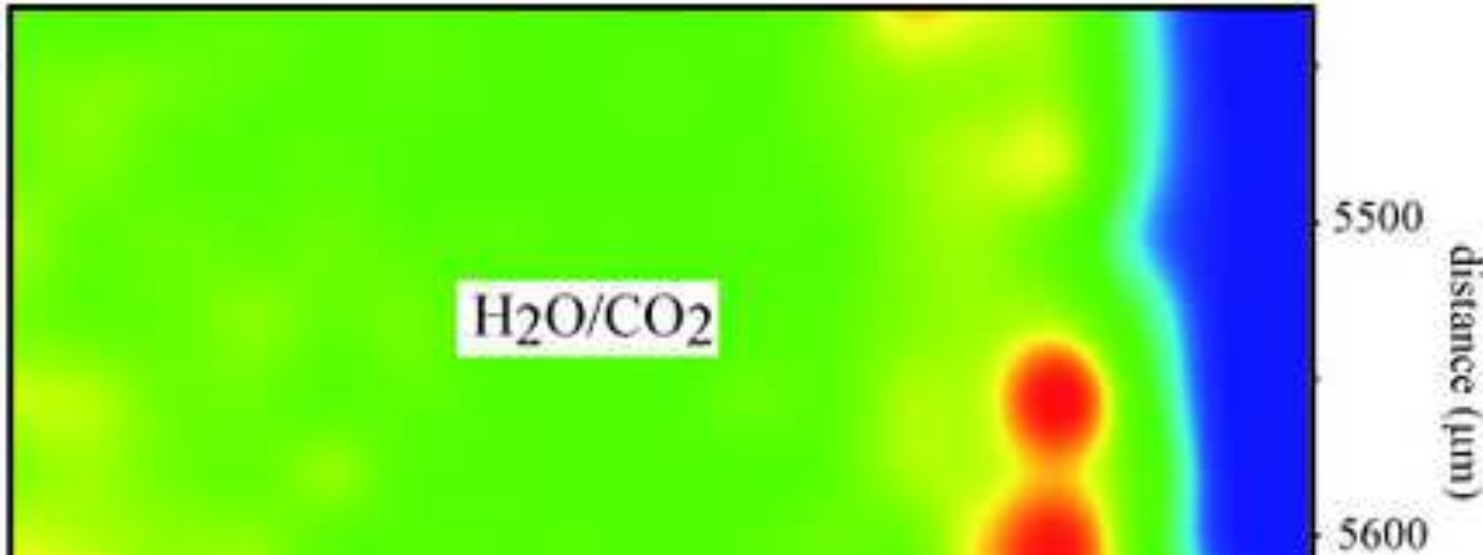

1900

1800

1700

1600

distance $(\mu \mathrm{m})$

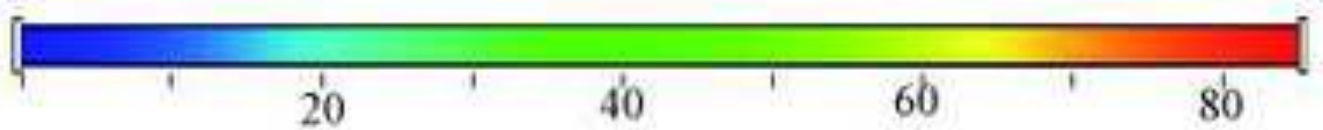

intensity (h3530 $\left.\mathrm{cm}^{-1} / \mathrm{h} 1515 \mathrm{~cm}^{-1}\right)$

Pichavant et al. Figure 7 


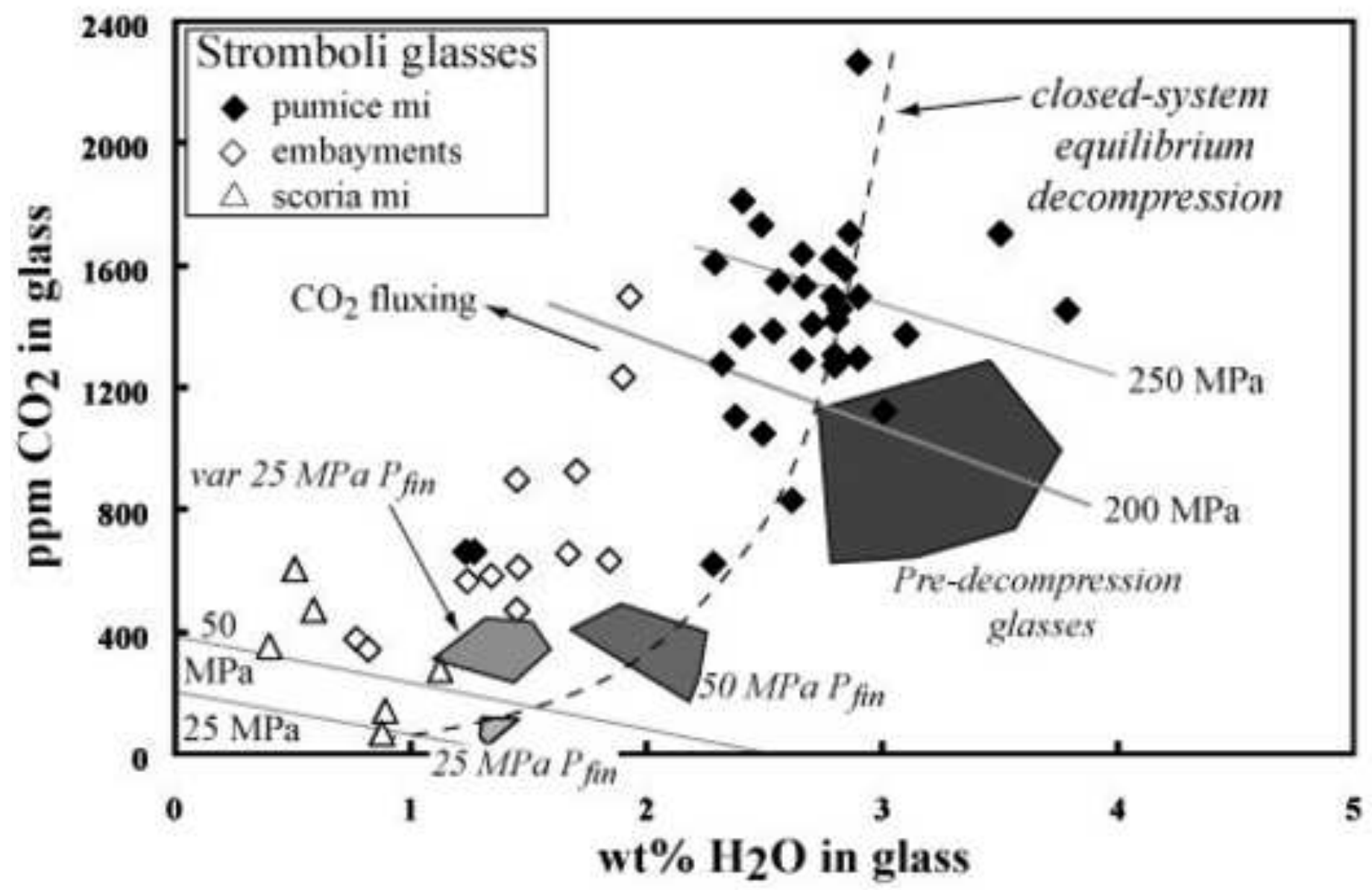

Pichavant et al. Fig. 9 
Table 1. Synthesis experiments

\begin{tabular}{|c|c|c|c|c|c|c|c|c|c|}
\hline Run \# & Charge & $\begin{array}{l}\text { PST-9 } \\
\text { starting } \\
\text { material }\end{array}$ & $\begin{array}{l}\mathrm{XH}_{2} \mathrm{O} \text { in. } \\
\text { mol. }\end{array}$ & $\begin{array}{l}\% \text { fluid } \\
\text { wt. }\end{array}$ & $\begin{array}{l}\mathrm{T} \\
{ }^{\circ} \mathrm{C}\end{array}$ & $\begin{array}{l}\mathrm{P} \\
\mathrm{MPa}\end{array}$ & $\begin{array}{l}\mathrm{t} \\
\mathrm{s}\end{array}$ & $\begin{array}{l}\mathrm{H}_{2} \mathrm{O} \text { glass } \\
\mathrm{wt} \%\end{array}$ & $\begin{array}{l}\mathrm{CO}_{2} \text { glass } \\
\text { ppm }\end{array}$ \\
\hline \multirow[t]{2}{*}{$\mathrm{S} 1$} & 1 & glass & 0.91 & 9.95 & 1150 & 199.6 & \multicolumn{2}{|c|}{ $7200 \mathrm{nd}$} & nd \\
\hline & 2 & glass & 0.90 & 10.01 & 1150 & 199.6 & $\sim 720$ & 3.13 (11) & $842(107)$ \\
\hline \multirow[t]{2}{*}{ S2 } & 3 & glass & 0.90 & 9.93 & 1150 & 199.8 & 7080 & $3.15(18)$ & $636(119)$ \\
\hline & 4 & glass & 0.90 & 9.73 & 1150 & 199.8 & 7080 & 3.57 (12) & $737(112)$ \\
\hline \multirow[t]{6}{*}{$\mathrm{S} 3$} & 5 & glass & 0.91 & 10.26 & 1150 & 197.5 & 8220 & nd & nd \\
\hline & 7 & glass & 0.90 & 10.11 & 1150 & 197.5 & 8220 & nd & nd \\
\hline & 8 & glass & 0.90 & 10.03 & 1150 & 197.5 & 8220 & nd & nd \\
\hline & 9 & glass & 0.92 & 9.45 & 1150 & 197.5 & 8220 & nd & nd \\
\hline & 10 & glass & 0.89 & 9.67 & 1150 & 197.5 & 8220 & nd & nd \\
\hline & 11 & glass & 0.90 & 9.90 & 1150 & 197.5 & 8220 & 2.77 (18) & $626(147)$ \\
\hline \multirow[t]{2}{*}{$\mathrm{S} 4$} & 12 & pumice & 0.80 & 10.22 & 1150 & 259 & 9300 & 3.77 (39) & 993 (95) \\
\hline & 13 & pumice & 0.80 & 9.83 & 1150 & 259 & 9300 & $3.63(32)$ & $922(164)$ \\
\hline \multirow[t]{2}{*}{ S5 } & 14 & glass & 0.63 & 10.26 & 1180 & 249.4 & 7920 & $3.46(11)$ & $1284(26)$ \\
\hline & 15 & glass & 0.50 & 10.22 & 1180 & 249.4 & 7920 & $2.74(10)$ & $1124(81)$ \\
\hline
\end{tabular}

The whole-rock composition (Pichavant et al. 2009) of PST-9 basaltic pumice is (wt\%): $\mathrm{SiO}_{2}: 49.4 ; \mathrm{TiO}_{2}: 0.79 ; \mathrm{Al}_{2} \mathrm{O}_{3}: 15.75$;

$\mathrm{Fe}_{2} \mathrm{O}_{3}: 1.3 ; \mathrm{FeO}: 6.5 ; \mathrm{MnO}: 0.15 ; \mathrm{MgO}: 7.96 ; \mathrm{CaO}: 12.73 ; \mathrm{Na}_{2} \mathrm{O}: 2.27 ; \mathrm{K}_{2} \mathrm{O}: 1.85 ; \mathrm{P}_{2} \mathrm{O}_{5}: 0.43$.

$\mathrm{XH}_{2} \mathrm{O}$ in. = initial molar $\mathrm{H}_{2} \mathrm{O} /\left(\mathrm{H}_{2} \mathrm{O}+\mathrm{CO}_{2}\right)$ in the charge.

$\%$ fluid $=$ weight proportion of $\mathrm{H}_{2} \mathrm{O}+\mathrm{CO}_{2}$ in the charge.

nd: not determined. 
Table 2. Decompression experiments

\begin{tabular}{|c|c|c|c|c|c|c|c|c|c|c|c|c|}
\hline Run \# & Charge & $\begin{array}{l}\text { Starting } \\
\text { glass }\end{array}$ & $\begin{array}{l}\mathrm{T} \\
{ }^{\circ} \mathrm{C}\end{array}$ & $\begin{array}{l}\mathrm{P}_{\text {init }} \\
\mathrm{MPa}\end{array}$ & $\begin{array}{l}\mathrm{P}_{\text {fin1 } 1} \\
\mathrm{MPa}\end{array}$ & $\begin{array}{l}\mathrm{t}_{\mathrm{ramp} 1} \\
\mathrm{~s}\end{array}$ & $\begin{array}{l}\mathrm{V}_{\text {ramp1 }} \\
\mathrm{m} / \mathrm{s}\end{array}$ & $\begin{array}{l}\mathrm{P}_{\text {fin2 }} \\
\mathrm{MPa}\end{array}$ & $\begin{array}{l}\mathrm{t}_{\mathrm{ramp} 2} \\
\mathrm{~s}\end{array}$ & $\begin{array}{l}\mathrm{V}_{\text {ramp2 }} \\
\mathrm{m} / \mathrm{s}\end{array}$ & $\begin{array}{l}\text { Bubbles } \\
\text { vol\% }\end{array}$ & Crystals \\
\hline R1 & $\begin{array}{l}\left.1 \text { (blocks }^{\mathrm{a}}\right) \\
2 \text { (powder) } \\
3 \text { (pumice) }\end{array}$ & $\begin{array}{l}\mathrm{S} 1^{\mathrm{b}} \\
\mathrm{S} 1 \\
-\end{array}$ & $\begin{array}{l}1150 \\
1150 \\
1150\end{array}$ & $\begin{array}{l}195.3 \\
195.3 \\
195.3\end{array}$ & $\begin{array}{l}45 \\
45 \\
45\end{array}$ & $\begin{array}{l}9000 \\
9000 \\
9000\end{array}$ & $\begin{array}{l}0.64 \\
0.64 \\
0.64\end{array}$ & $\begin{array}{l}- \\
- \\
-\end{array}$ & $\begin{array}{l}- \\
- \\
-\end{array}$ & $\begin{array}{l}- \\
- \\
-\end{array}$ & $\begin{array}{l}3^{\mathrm{d}} \\
3^{\mathrm{d}} / 1^{\mathrm{e}} \\
0^{\mathrm{d}}\end{array}$ & $\begin{array}{l}- \\
- \\
-\end{array}$ \\
\hline R4 & $\begin{array}{l}1 \text { (blocks) } \\
2 \text { (powder) } \\
3 \text { (pumice) }\end{array}$ & $\begin{array}{l}\mathrm{S} 2 \\
\mathrm{~S} 2 \\
-\end{array}$ & $\begin{array}{l}1150 \\
1150 \\
1150\end{array}$ & $\begin{array}{l}199.7 \\
199.7 \\
199.7\end{array}$ & $\begin{array}{l}47.7 \\
47.7 \\
47.7\end{array}$ & $\begin{array}{l}5700 \\
5700 \\
5700\end{array}$ & $\begin{array}{l}1.03 \\
1.03 \\
1.03\end{array}$ & $\begin{array}{l}- \\
- \\
-\end{array}$ & $\begin{array}{l}- \\
-\end{array}$ & $\begin{array}{l}- \\
- \\
-\end{array}$ & $\begin{array}{l}3^{d} \\
4^{d} / 3^{e} \\
5^{d}\end{array}$ & $\begin{array}{l}\text { quench } \\
\text { quench } \\
\text { - }\end{array}$ \\
\hline R16 & $\begin{array}{l}1 \text { (powder) } \\
2 \text { (powder) }\end{array}$ & $\begin{array}{l}\text { S3 } \\
\text { S5 }\end{array}$ & $\begin{array}{l}1180 \\
\rightarrow 11 \\
1180 \\
\rightarrow 11\end{array}$ & $\begin{array}{l}250 \\
50^{c} \\
250 \\
50^{c}\end{array}$ & $\begin{array}{l}50 \\
50\end{array}$ & 29970 & 0.26 & - & - & - & $\begin{array}{l}3^{d} \\
5^{d}\end{array}$ & $\mathrm{cpx}, \mathrm{ol}$ \\
\hline R5 & $\begin{array}{l}1 \text { (powder) } \\
2 \text { (blocks) }\end{array}$ & $\begin{array}{l}\mathrm{S} 2 \\
\mathrm{~S} 2\end{array}$ & $\begin{array}{l}1150 \\
1150\end{array}$ & $\begin{array}{l}201 \\
201\end{array}$ & $\begin{array}{l}50 \\
50\end{array}$ & $\begin{array}{l}5640 \\
5640\end{array}$ & $\begin{array}{l}1.03 \\
1.03\end{array}$ & $\begin{array}{l}24.8 \\
24.8\end{array}$ & $\begin{array}{l}960 \\
960\end{array}$ & $\begin{array}{l}1.01 \\
1.01\end{array}$ & $\begin{array}{l}8^{\mathrm{d}} \\
13^{\mathrm{d}} / 11^{\mathrm{e}}\end{array}$ & $\begin{array}{l}\text { quench } \\
\text { quench }\end{array}$ \\
\hline R10 & $\begin{array}{l}1 \text { (powder) } \\
2 \text { (blocks) }\end{array}$ & $\begin{array}{l}\text { S3 } \\
\text { S3 }\end{array}$ & $\begin{array}{l}1150 \\
1150\end{array}$ & $\begin{array}{l}197.4 \\
197.4\end{array}$ & $\begin{array}{l}50 \\
50\end{array}$ & $\begin{array}{l}8880 \\
8880\end{array}$ & $\begin{array}{l}0.64 \\
0.64\end{array}$ & $\begin{array}{l}25 \\
25\end{array}$ & $\begin{array}{l}1500 \\
1500\end{array}$ & $\begin{array}{l}0.64 \\
0.64\end{array}$ & $\begin{array}{l}18^{\mathrm{d}} / 20^{\mathrm{e}} \\
10^{\mathrm{d}} / 9^{\mathrm{e}}\end{array}$ & - \\
\hline R11 & $\begin{array}{l}1 \text { (pumice) } \\
2 \text { (powder) }\end{array}$ & $\begin{array}{l}- \\
\text { S3 }\end{array}$ & $\begin{array}{l}1150 \\
1150\end{array}$ & $\begin{array}{l}196.2 \\
196.2\end{array}$ & $\begin{array}{l}50 \\
50\end{array}$ & $\begin{array}{l}3840 \\
3840\end{array}$ & $\begin{array}{l}1.46 \\
1.46\end{array}$ & $\begin{array}{l}25 \\
25\end{array}$ & $\begin{array}{l}3840 \\
3840\end{array}$ & $\begin{array}{l}0.25 \\
0.25\end{array}$ & $\begin{array}{l}\text { nd } \\
\text { nd }\end{array}$ & $\begin{array}{l}\text { sph } \\
\text { sph }\end{array}$ \\
\hline
\end{tabular}




\begin{tabular}{|c|c|c|c|c|c|c|c|c|c|c|c|}
\hline \multirow[t]{3}{*}{$\mathrm{R} 12$} & 1 (pumice) & - & $1150 \quad 258.4$ & 50 & 7980 & 1.00 & 25 & 1860 & 0.52 & $0^{\mathrm{d}}$ & - \\
\hline & 2 (powder) & S3 & $1150 \quad 258.4$ & 50 & 7980 & 1.00 & 25 & 1860 & 0.52 & $1^{\mathrm{d}}$ & - \\
\hline & 3 (powder) & S4 & $1150 \quad 258.4$ & 50 & 7980 & 1.00 & 25 & 1860 & 0.52 & $1^{\mathrm{d}}$ & - \\
\hline \multirow[t]{2}{*}{ R13 } & 1 (powder) & $\mathrm{S} 3$ & $\begin{array}{l}1150 \quad 253 \\
\rightarrow 1140^{c}\end{array}$ & 50 & 7620 & 1.02 & 25 & 1920 & 0.50 & $2^{\mathrm{d}}$ & - \\
\hline & 2 (powder) & $\mathrm{S} 4$ & $\begin{array}{l}1150 \quad 253 \\
\rightarrow 1140^{\mathrm{c}}\end{array}$ & 50 & 7620 & 1.02 & 25 & 1920 & 0.50 & $4^{\mathrm{d}}$ & - \\
\hline $\mathrm{R} 14$ & 1 (powder) & S5 & $\begin{array}{l}1180 \quad 248.4 \\
\rightarrow 1150^{c}\end{array}$ & 50 & 4590 & 1.66 & 25 & 1860 & 0.52 & $0^{\mathrm{d}} / 0^{\mathrm{e}}$ & - \\
\hline $\mathrm{R} 15$ & 3 (powder) & S5 & $\begin{array}{l}1180 \quad 261.7 \\
\rightarrow 1150^{\mathrm{c}}\end{array}$ & 50 & 4740 & 1.72 & 25 & 3780 & 0.25 & $0^{\mathrm{d}}$ & - \\
\hline
\end{tabular}

The decompression path is divided in two parts, ramp 1 above $\sim 50 \mathrm{MPa}$ and ramp 2 between $\sim 50$ and $\sim 25 \mathrm{MPa}$. T: run temperature; $\mathrm{P}_{\text {init: }}$ : pressure at the beginning of decompression path. For each ramp, $\mathrm{P}_{\text {fin }}$ : pressure at the end of decompression ramp; $\mathrm{v}_{\text {ramp }}$ : ascent/decompression rate $\left(=10^{6}\left(\mathrm{P}_{\text {init }}-\mathrm{P}_{\text {fin }}\right) /\left(\mathrm{g} \mathrm{d} \mathrm{t}_{\text {ramp }}\right)\right)$, with $\mathrm{g}=9.81 \mathrm{~m} / \mathrm{s}^{2}, \mathrm{~d}=2650 \mathrm{~kg} / \mathrm{m}^{3}$ and $\mathrm{t}_{\text {ramp }}=$ duration of the ramp. For ramp $2, \mathrm{P}_{\text {init }}=\mathrm{P}_{\text {fin } 1}$.

R1, R4, R16, R5, R10: constant decompression experiments (either decompression ended at $\sim 50 \mathrm{MPa}$ or decompression ended at $\sim 25 \mathrm{MPa}$ but $\mathrm{v}_{\mathrm{ramp1}}=\mathrm{v}_{\mathrm{ramp} 2}$ ); R11, R12, R13, R14, R15: variable decompression experiments (decompression ended at $\sim 25 \mathrm{MPa}$ but $\mathrm{v}_{\mathrm{ramp} 1} \neq \mathrm{v}_{\text {ramp2 }}$ ).

${ }^{\text {a } P h y s i c a l ~ s t a t e ~ o f ~ t h e ~ s t a r t i n g ~ m a t e r i a l . ~ B l o c k s: ~ s m a l l ~ g l a s s ~ b l o c k s ; ~ p o w d e r: ~ g l a s s ~ p o w d e r ; ~ p u m i c e: ~ p u m i c e ~ p o w d e r . ~}$

${ }^{\mathrm{b}}$ Glass synthesis batch number.

${ }^{\mathrm{c}}$ Non-isothermal experiment; temperature varied linearly along the decompression path.

Vol\% bubbles from 2D image analysis ${ }^{\mathrm{d}}$ or $3 \mathrm{D}$ X-ray microtomography ${ }^{\mathrm{e}}$ (see text and Table 4).

quench: quench crystals identified from SEM observations; sph: minor amounts of small spherulitic crystals; cpx: clinopyroxene, ol, olivine; -: crystal-free charge. 
Table 3. FTIR data

\begin{tabular}{|c|c|c|c|c|c|c|c|}
\hline Run\# & Charge\# & $\mathrm{n}^{\mathrm{a}}$ & $\begin{array}{l}\text { Thickness } \\
\mu \mathrm{m}\end{array}$ & $\begin{array}{l}\text { Absorbance } \\
3530 \mathrm{~cm}^{-1}\end{array}$ & $\begin{array}{l}\mathrm{H}_{2} \mathrm{O} \\
\mathrm{wt} \%\end{array}$ & $\begin{array}{l}\text { Absorbance } \\
1515 \mathrm{~cm}^{-1}\end{array}$ & $\begin{array}{l}\mathrm{CO}_{2} \\
\mathrm{ppm}\end{array}$ \\
\hline $\mathrm{S} 1$ & 2 & 3 & $50(1)^{b}$ & $1.488(23)$ & $3.13(11)$ & $0.093(10)$ & 842 (107) \\
\hline \multirow[t]{2}{*}{$\mathrm{S} 2$} & 3 & 3 & $64(4)$ & $1.909(17)$ & 3.15 (18) & 0.089 (12) & 636 (119) \\
\hline & 4 & 3 & $40(2)$ & $1.354(100)$ & 3.57 (12) & $0.065(10)$ & 737 (112) \\
\hline S3 & 11 & 4 & $56(12)$ & $1.467(262)$ & $2.77(18)$ & $0.080(32)$ & $626(147)$ \\
\hline \multirow[t]{2}{*}{$\mathrm{S} 4$} & 12 & 4 & $40(5)$ & $1.410(167)$ & 3.77 (39) & 0.087 (12) & $993(95)$ \\
\hline & 13 & 3 & $48(3)$ & $1.636(130)$ & $3.63(32)$ & $0.096(16)$ & $922(164)$ \\
\hline \multirow[t]{2}{*}{ S5 } & 14 & 6 & $53(2)$ & $1.739(64)$ & $3.46(11)$ & $0.147(4)$ & $1284(26)$ \\
\hline & 15 & 6 & $72(2)$ & $1.888(101)$ & $2.74(10)$ & $0.179(10)$ & $1124(81)$ \\
\hline \multirow[t]{3}{*}{$\mathrm{R} 1$} & 1 & 4 & $46(3)$ & $0.749(27)$ & $1.70(13)$ & $0.041(18)$ & 408 (184) \\
\hline & 2 & 3 & $44(2)$ & $0.793(95)$ & $1.89(18)$ & $0.046(5)$ & $469(37)$ \\
\hline & 3 & 4 & $46(3)$ & 0.97 (113) & $2.23(24)$ & $0.040(14)$ & 397 (142) \\
\hline \multirow[t]{5}{*}{$\mathrm{R} 4$} & 1 & 3 & $45(3)$ & $0.877(95)$ & $2.03(20)$ & $0.034(15)$ & 337 (134) \\
\hline & 2 & 3 & $51(1)$ & $1.079(31)$ & $2.20(2)$ & $0.028(8)$ & $243(74)$ \\
\hline & 3 & 3 & $39(3)$ & $0.756(21)$ & $2.05(17)$ & $0.001(2)$ & $<50^{\mathrm{c}}$ \\
\hline & 3 & 5 & $147(5)$ & $>>2$ & nd & $0.196(13)$ & $598(27)$ \\
\hline & 3 & av. & & & $2.05(17)$ & & 379 (303) \\
\hline \multirow[t]{2}{*}{ R16 } & $1 *$ & 3 & $41(3)$ & 0.398 & $1.00(4)$ & $0.001(2)$ & $<50^{\mathrm{c}}$ \\
\hline & 2 & 3 & $28(2)$ & $0.592(89)$ & $2.18(20)$ & $0.014(30)$ & $198(442)$ \\
\hline \multirow[t]{2}{*}{ R5 } & 1 & 3 & 47 (1) & $0.605(18)$ & $1.34(6)$ & $0.000(0)$ & $<50^{\mathrm{c}}$ \\
\hline & 2 & 3 & $50(1)$ & $0.635(26)$ & $1.32(4)$ & $0.000(0)$ & $<50^{\mathrm{c}}$ \\
\hline \multirow[t]{2}{*}{$\mathrm{R} 10$} & 1 & 4 & $48(3)$ & $0.618(24)$ & $1.33(10)$ & $0.011(4)$ & 102 (39) \\
\hline & 2 & 4 & $48(8)$ & $0.647(48)$ & $1.43(16)$ & $0.011(8)$ & $101(92)$ \\
\hline \multirow[t]{2}{*}{$\mathrm{R} 12$} & 1 & 4 & $28(2)$ & $0.420(23)$ & $1.55(17)$ & $0.000(0)$ & $<50^{\mathrm{c}}$ \\
\hline & 1 & 4 & $46(5)$ & $0.634(72)$ & $1.43(11)$ & $0.034(30)$ & 308 (242) \\
\hline
\end{tabular}




\begin{tabular}{llllllll} 
& 1 & 5 & $164(18)$ & $2.109(80)$ & $1.34(12)$ & $0.176(8)$ & $483(35)$ \\
& 1 & av. & & & $1.43(15)$ & & $257(244)$ \\
& 2 & 3 & $58(9)$ & $0.771(65)$ & $1.39(14)$ & $0.038(16)$ & $297(117)$ \\
$\mathrm{R} 13$ & 3 & 3 & $51(3)$ & $0.771(54)$ & $1.57(2)$ & $0.040(26)$ & $344(210)$ \\
& 1 & 3 & $57(4)$ & $0.709(47)$ & $1.29(16)$ & $0.038(11)$ & $298(105)$ \\
$\mathrm{R} 14$ & 2 & 3 & $49(5)$ & $0.706(59)$ & $1.51(15)$ & $0.044(9)$ & $408(115)$ \\
$\mathrm{R} 14$ & - & 4 & $64(4)$ & $0.707(139)$ & $1.14(21)$ & $0.064(28)$ & $446(196)$ \\
& - & 6 & $144(0)$ & $1.577(23)$ & $1.13(2)$ & $0.069(10)$ & $215(32)$ \\
$\mathrm{R} 15$ & - & av. & & & $1.14(11)$ & & $302(161)$ \\
$\mathrm{R} 15$ & - & 3 & $53(3)$ & $0.681(77)$ & $1.34(21)$ & $0.058(36)$ & $499(320)$ \\
& - & 6 & $156(0)$ & $1.974(5)$ & $1.31(0)$ & $0.133(15)$ & $380(42)$ \\
& - & & & & $1.32(11)$ & & $420(174)$ \\
\hline
\end{tabular}

${ }^{\mathrm{a}}$ Number of analytical spots.

${ }^{\mathrm{b}}$ One standard deviation in terms of the last digit.

${ }^{\mathrm{c}} \mathrm{CO}_{2}$ below detection limit (50 ppm). The data are plotted with a concentration of $50 \mathrm{ppm}$ in figs. 4 and 6.

S1 to S5: glass synthesis experiments; R1 to R16: decompression experiments.

R4-3, R14, R15 analyzed in duplicate; R12-1 analyzed in triplicate. Average $\mathrm{H}_{2} \mathrm{O}$ and $\mathrm{CO}_{2}$ concentrations (av.) and standard deviations are reported. These are calculated by using all analytical spots.

*R16-1 contains on average $12 \mathrm{wt} \%$ crystals as determined by mass balance calculations. Therefore, $\mathrm{H}_{2} \mathrm{O}$ and $\mathrm{CO}_{2}$ values given are minimum concentrations and the data are not plotted.

nd: not determined (absorbance $>>2$ ). 
Table 4. X-ray microtomography data

\begin{tabular}{|c|c|c|c|c|c|c|c|}
\hline \multirow[t]{2}{*}{ Run\# } & \multirow[t]{2}{*}{ Charge\# } & \multicolumn{6}{|c|}{ Bubble 3D characteristics } \\
\hline & & $\mathrm{n}$ & pk. size $(\mu \mathrm{m})$ & range $(\mu \mathrm{m})$ & av. size $(\mu \mathrm{m})$ & vol\% & $\operatorname{BND}\left(\mathrm{cm}^{-3}\right)$ \\
\hline $\mathrm{R} 1$ & 2 & 268 & $10-20$ & $10-110$ & $29(20)$ & 1 & $3.25 \times 10^{5}$ \\
\hline $\mathrm{R} 4$ & 2 & 70 & $10-20$ & $10-130$ & $34(23)$ & 3 & $5.47 \times 10^{5}$ \\
\hline R5 & 2 & 390 & $40-50$ & $10-330$ & $59(38)$ & 11 & $3.99 \times 10^{5}$ \\
\hline R10 & $\begin{array}{l}1 \\
2\end{array}$ & $\begin{array}{l}5 \\
8\end{array}$ & $\begin{array}{l}\text { nd } \\
\text { nd }\end{array}$ & $\begin{array}{l}\text { nd } \\
\text { nd }\end{array}$ & $\begin{array}{l}270(25) \\
190(15)\end{array}$ & $\begin{array}{l}20 \\
9\end{array}$ & $\begin{array}{l}2.45 \times 10^{4} \\
2.78 \times 10^{4}\end{array}$ \\
\hline R14 & - & 0 & - & - & 0 & 0 & $<10^{2}$ \\
\hline
\end{tabular}

X-ray microtomographic data acquired on 1-10 $\mathrm{mm}^{3}$ fragments.

$\mathrm{n}$ : number of bubbles counted in the analyzed volume.

pk. size: maximum of the bubble diameter histogram.

range: total range of bubble diameters.

av. size: average bubble diameter; number in brackets is the standard deviation.

vesicularity: volume fraction of bubbles.

BND: number of bubbles per unit volume (BND). Detection limit is 1 bubble per $10 \mathrm{~mm}^{3}$, or $10^{2}$ bubbles per $\mathrm{cm}^{3}$. 